Graduate Institute of

International Studies I Geneva

Economics

HEI Working Paper No: 03/2005

\title{
How to Exit From Fixed Exchange Rate Regimes?
}

\author{
Ahmet Atil Asiçi \\ Graduate Institute of International Studies \\ Nadezhda Ivanova \\ Graduate Institute of International Studies \\ Charles Wyplosz \\ Graduate Institute of International Studies
}

\begin{abstract}
This paper improves upon the recently developed literature on exits from fixed exchange rate regimes in three ways: 1) It allows for two indicators for post-exit macroeconomic conditions, the change in the excange rate and the change in the output gap; 2) it tests whether the distinction between orderly and disorderly exit is statistically justified, and concludes that it is not; 3) it deals with the sample selection problem. The results, subject to extensive sensitivity analysis, suggest that post-exits are better when depegging occur in good macroeconomic conditions - an unnatural move for most policymakers - when world interest rates decline and in the presence of capital controls. Importantly, "good" macroeconomic policies do not seem to help with post-exit performance.
\end{abstract}

(C) The Authors.

All rights reserved. No part of this paper may be reproduced without the permission of the authors. 


\title{
How to Exit From Fixed Exchange Rate Regimes?
}

\author{
Ahmet Atıl Aşıcı \\ Graduate Institute of International Studies \\ Nadezhda Ivanova \\ Graduate Institute of International Studies \\ Charles Wyplosz \\ Graduate Institute of International Studies and CEPR
}

June 2005

JEL classification: C14, C34, F30, F31, F41,

We are grateful for useful comments and suggestions offered at various presentations. In particular, we wish to thank Manuel Arellano, Bob McCauley, Sebastian Edwards, Hans Genberg, Bo Honore, Phil Lane, Hélène Rey and Alexandre Swoboda. Ivanova and Wyplosz have been supported by a grant from the Swiss National Foundation and Aşıcı by the NCCR FINRISK project on 'Macro Risks, Systematic Risks and International Finance'. 


\section{Introduction}

Even though they can last for decades, fixed exchange rate regimes are increasingly seen as temporary arrangements, (Eichengreen, 1994). The hollowing out hypothesis, see, e.g. Fischer (2001), holds that fixed but adjustable exchange rate regimes of various kinds are scheduled to disappear in favor of either rigidly fixed rates (dollarization or currency boards) or free floats. The evidence so far is mixed but suggests that pegged regimes are not indeed fit for survival. For instance, in their comprehensive analysis Husain et al. (2004) report that, taken together, exchange rate regimes have an average duration of about 11 years in the post-Bretton Woods period. They also find that fixed regimes last longer than free floats for all countries taken together, but with sharp differences across country groupings. In particular, freely floating regimes last considerably longer among the group of developed countries while pegged regimes exhibit low duration in the group of emerging market countries, about 8 years. ${ }^{1}$ Extrapolating their observed transition probabilities, they predict a decline in pegged regimes. Furthermore, if countries "graduate" from the developing to the emerging markets category and from the latter to advanced, their transition probabilities predict a widespread move to floating.

Against this background, exits from pegged regimes are often marked by severe crises. Some exits are unwanted and forced by speculative attacks, as has been the case during the late 1990s waves of crises in Latin America, Russia and South East Asia. Other exits are voluntary but may turn out to be followed by attacks as well, as was the case in Mexico in 1995, for instance. An important question, therefore, is how to exit a pegged regime and avoid a crisis.

Curiously, this important policy issue has not attracted much interest so far. The only theoretical contribution that deals with the conditions under which exits are orderly is Rebelo and Végh (2002). This paper studies the optimal time for depegging when shocks occur; the main message is: the earlier, the better once the shock makes depegging unavoidable. The empirical literature is not much wider. Along with Aşıc1 and Wyplosz (2003), Eichengreen and Masson (1998) is the only paper that directly examines exit strategies. It is a broad-ranging case study, which reaches conclusions are in line with Rebelo and Végh (2002): exits are more likely to be orderly when undertaken in favorable conditions (sound macroeconomics, adequate banking systems and a period of capital inflows).

Five other closely related empirical papers look at developed, emerging market and developing countries. Klein and Marion (1997) examine the determinants of de-pegging, which includes both realignments within an exchange rate regime and exits to a more flexible regime. They do not distinguish among these two categories, nor do they examine the conditions under which de-pegging is orderly or not.

Extending Klein and Marion (1997), Duttagupta and Otker-Robe (2003) also search for the determinants of depegging. They use a multinomial logit procedure to allow for five

\footnotetext{
${ }^{1}$ Looking at pegs - i.e. not at regimes - Klein and Marion (1997) document that pegs have a median duration of 10 months.
} 
different outcomes: realignments within the same regime, orderly exits to more or to less flexible regimes, and "exchange rate pressure episodes", which may occur within the same exchange rate regime or not.

The third closely related paper is Masson and Ruge-Murcia (2003), which focuses entirely on exits. They estimate time-varying transition probabilities among three exchange rate regimes (fixed, intermediate, flexible) and then attempt to explain the estimated probabilities with macroeconomic factors. Interestingly, they use the transition probabilities to describe the long run distribution of exchange rate regimes.

Agénor (2004) asks similar questions and provides an in-depth study of three exit episodes, examining the behavior of capital flows in some detail. He focuses on intermediate regimes, thus allowing exits to hard pegs as well as to free floating.

Detragiache et al. (2005) is closest to the present paper. It uses multinomial logits to estimate the difference between orderly and disorderly exits, using no exits as the reference situation. Put differently, it attempts to explain exits, and seeks to find out whether orderly and disorderly exits are different. They find little evidence that this is the case, maybe for reasons that can be explained by our findings. Their paper differs from ours in the definition of exits as well as in the distinction between orderly and disorderly exits. These differences are indicated below.

The present paper is an extension of Aşıc1 and Wyplosz (2003). Using a sample of 55 exits, involving both developed and developing countries, that paper estimates the characteristics of orderly exits, defined as a moderate exchange rate depreciation of the exchange rate over the post-exit period. Beyond an expanded dataset, five additional steps are taken here. The first one concerns the characterization of exits as orderly or not. We present evidence that this distinction is arbitrary and can therefore lead to incorrect inference. Second, since many exits have been followed by sharp depreciations, it seems natural to look at the post-exit evolution of the exchange rate but another valid consideration is the post-exit growth performance. The third step concerns the methodology. Focusing on exiting countries creates an obvious sample selection problem. Countries exit for some specific reasons, which may affect post-exit conditions. We deal with this problem by using Heckman's selection model, which allows us to estimate both the probability of an exit from a pegged exchange rate regime and the effects of the exit. Fourth, given the results in Husain et al. (2004) that reveal different patterns in developed and emerging market countries, it is desirable to check whether depegging differs systematically across various country groupings. Finally, we perform an extensive set of sensitivity tests.

The main results are summarized in Table 10 and commented upon in the concluding section. By and large, they support the view that countries tend to wait too long to leave a pegged exchange rate regime and that the best time to do so is when economic conditions, both at home and abroad, are favorable, an un-natural step for policymakers. The results also fail to support the view that policy rectitude, with its tell-tale signals of 
balanced budgets and current accounts, provides a necessary background for a successful exit.

The next section presents our sample and data. Section 3 explains the sample selection problem and presents the methodology that is adopted to deal with it. Section 4 offers a review of relevant existing theories to motivate the choice of the explanatory variables. The results are presented in the following section, which also includes extensive sensitivity tests. The last section concludes.

\section{Data and Sample}

\subsection{Definition of Exit}

We first need to identify exits. This raises two main difficulties: we must evaluate the true commitment of the monetary authorities to a target or a range and then established a dividing line between pegged and freely floating exchange rates. As is now well documented (Levy-Yeyati and Sturzenegger, 2005; Reinhart and Rogoff, 2004) actual exchange regimes may differ from those officially announced by the authorities. In addition, the exchange regime is not a black-and-white issue; many intermediate arrangements exist, with varying degrees of commitment and flexibility. To deal with this set of issues, we follow the literature and use the classification proposed by Reinhart and Rogoff (R\&R, hereafter) on the basis of an algorithm that examines the actual behavior of exchange rates. ${ }^{2}$ This classification defines 13 exchange regime categories that range from the absence of a domestic currency (dollarization) to a pure free float. $R \& R$ also distinguish an additional category - freely falling - corresponding to high inflation and continuing depreciation, within which they rank countries along the previous 13 categories. For this category, we use their secondary classification to determine the exchange rate regime, in effect ignoring the fact that the exchange rate is freely falling, but we also perform a sensitivity test where we discard instead the freely falling category.

R\&R regroup their 13 fine categories into four broad classes, as described in Table 1: pegs, limited flexibility, managed float and floating rates. In order to identify exit episodes, we need to further narrow down this classification to just two regimes, fixed and floating. The criterion that we use is whether there is any commitment, official or implicit, to maintain the exchange rate within limits, possibly wide ones. The rationale is that any such commitment stands to be challenged by the markets, in which case the central bank must decide whether to uphold the set limits. As long as the central bank stands ready to honor its commitment, it does not matter whether the band is narrow or wide, horizontal or moving. This logic implies that the border between fixed and floating rates is as indicated in the two-way benchmark classification shown in Table 1. The resulting list of exits is shown in the Appendix, Table A1.

\footnotetext{
2 The authors do not use the official exchange rates but "black market" rates meant to capture actual transaction rates in the presence of dual markets or curb markets.
} 


\subsection{Sample}

The use of R\&R's exchange rate regime classification determines the sample; it ends in 2000 (plus one observation, Turkey's exit in 2001). We only consider the post-Bretton Woods period, starting in 1975 . We generally use monthly variables, even though some series are only available at the annual frequency, see below.

We start with 799 observations, which yield 57 exits and 742 no-exits. As explained below, both exit and no-exit cases are built by using a three-year exclusion window. Among the no-exit observations we exclude 201 observations for countries belonging to currency unions, which leaves us with 541 observations of no-exits. ${ }^{3}$ The excluded currency-union countries are listed in Appendix Table A3.

The total sample of 799 observations includes 128 countries: 103 developing countries and 25 developed countries. The sample of 598 observations used in the regressions includes 106 countries: 82 developing countries and 24 developed countries. The number of exiting countries is 49 (40 developing and 9 developed countries); for six developing countries and two developed countries there are two exit observations. Non-exiting observations concern 57 countries that never exited and 39 countries that exited at least once. Appendix Tables A1 and A2 provide the list of all exit and no-exit cases.

\subsection{Exits and No-Exits}

For each exit case we apply a three-year exclusion window, which covers the 24 preceding months and the subsequent 12 months $(t-24$ to $t+12)$. This is designed to eliminate cases of rapid re-pegging, possibly followed by rapid exit, which we consider as one exit event, the first one. The longer pre-exit period is chosen to ensure that we only deal with cases where the peg has been in place for a substantial period before exit. ${ }^{4}$

No-exit cases are arbitrary in the sense that nothing happens. The chosen procedure is to apply the same three-year exclusion window as in the exit cases. To that effect, for each country, we adopt the following procedure:

- If the country never exits during the sample period, we partition the period in as many three year sub-periods as possible, leaving out what remains at the end. Each of these three-year sub-periods is treated as the no-exit analog of the exit cases, i.e. $t=0$ corresponds to the observation two years after the beginning of the sub-period. - If the country exited once, we start from the exit case and its associated three-year window. From there, we move to the left and to the right and identify as many three-year windows as possible.

\footnotetext{
${ }^{3}$ The exclusion of currency unions is motivated by the finding in Edwards and Magendzo (2003) that dollarized and currency unions differ in relevant aspects from other economies.

${ }^{4}$ Some exit dates differ slightly from those established by R\&R. Their algorithm assigns an exchange rate regime when it has been in place for at least $80 \%$ of the time over a 5-year rolling period. As a result, an exit may have taken place up to 12 months before the date given in their chronologies. We have adjusted some dates given after carefully checking the evolution of the rate. We are grateful to Hans Genberg for raising this point.
} 
- If there are several exit cases, we proceed as above, filling up the periods in-between exits and both ends with as many three-year windows as possible. Since there are many ways of filling the periods in-between exits, we arbitrarily move leftwards.

\section{Methodology}

\subsection{The Sample Selection Problem}

We wish to determine what factors determine the post-exit conditions. As we limit our analysis to countries that have exited a pegged regime, we face a sample selection bias if some of the factors that affect the decision to exit also affect the exit outcome. Duttagupta and Otker-Robe (2003) and Detragiache et al. (2005) avoid this problem by resorting to multinomial logit which jointly estimate various exchange rate regime transitions, including the absence of exit. An alternative solution is to use the sample selection model described in Heckman (1979). The logic can be briefly recalled as follows. For country $i$ and period $t$, the regression of interest is:

$$
y_{i, t}=X_{i, t} b+u_{1 i, t}
$$

where $y_{i, t}$ is a measure of post-exit conditions and $X_{i, t}$ the factors of interest. This regression equation can be classic or limited dependent (probit, logit), but sample selection occurs when $y_{i, t}$ is only observed if the country is exiting. Defining the auxiliary variable $z_{i, t}$, with $z_{i, t} \leq 0$ if country $i$ does not exit in period $t$ and $z_{i, t}>0$ if it does, we can specify an exit equation, the selection equation in Heckman (1979):

$$
z_{i, t}=W_{i, t} c+u_{2 i, t}
$$

which can, again be classical or limited dependent. Importantly the error terms, which are assumed to be normal, need not be independently distributed:

$$
u_{1} \sim \mathrm{N}\left(\mathrm{o}, \sigma_{1}^{2}\right), u_{2} \sim \mathrm{N}\left(\mathrm{o}, \sigma_{2}^{2}\right), \operatorname{cor}\left(u_{1}, u_{2}\right)=\rho
$$

The regression equation is therefore conditional on the dependent variable being observed, i.e. on $z_{i, t}>0$ :

$$
y_{i, t} \mid z_{i, t}>0=E\left(y_{i, t} \mid z_{i, t}>0\right)+v_{i, t}
$$

Heckman (1979) shows that this implies an omitted variable bias and that the correct regression is:

$$
y_{i, t}=X_{i, t} b+\rho \sigma_{1} \lambda_{i, t}+v_{i, t}
$$

where $\lambda_{i, t}=\varphi\left(W_{i, t} c / \sigma_{2}\right) / \Phi\left(W_{i, t} c / \sigma_{2}\right)$ is Mill's ratio, with $\varphi()$ the normal density function and $\Phi()$ its cumulative distribution. This omitted variable is retrieved from the probit estimation of the selection equation (2), where we use on the right-hand side a variable 
that takes the value of 1 in the case of an exit and 0 when the pegged exchange rate regime remains in place. ${ }^{5}$ This is a censored regression as the right-hand side variable can be defined as $z_{i, t}$ such that $z^{*}{ }_{i, t}=1$ if $z_{i, t}>0$ and $z_{i, t}=0$ if $z_{i, t} \leq 0$. The selection equation provides estimates of $\lambda_{i, t}$ and $\operatorname{var}\left(v_{i, t}\right)$, which are then used to estimate the regression equation (5) yielding (asymptotically) unbiased estimates of $b$ under the usual normality assumptions.

The model made of (2) and (5) can be estimated in two-steps as described above, or by joint maximum likelihood (ML). ML estimation is more efficient than the two-step procedure under the assumption of joint normality of the error terms, but it is less robust and may fail to converge (Wooldridge, 2002). We apply both estimators looking for the specifications, which are not sensitive to the estimation technique. We use panel data for all countries $i$ in our sample, therefore assuming that the coefficients in $b$ are the same for all countries.

\subsection{Endogenous variables}

The main purpose of this paper is to explore how best to exit. This requires a measure of the after-effects of exits. The literature, so far, has focused on the post-exit behavior of the nominal exchange rate. While it is obviously interesting to examine whether the exit results into a reasonably stable exchange rate, it is not the only question of interest. Another natural measure of exit performance is output behavior. We experiment with both. We consider both the change in the exchange rate relative to the anchor currency and the change in the output gap:

$$
\begin{array}{ll}
y_{i, t}=\log e_{i, t+6}-\log e_{i, t-6} & \text { Exchange rate indicator }^{6} \\
y_{i, t}=\text { output_gap } \text { gap }_{i, t+12}-\text { output_gap }_{i, t-12} & \text { Output indicator }^{7}
\end{array}
$$

The output gap is computed by detrending real GDP using the Hodrick-Prescott filter; it is measured as the logarithm of the ratio of actual to trend GDP in percent. The two chosen indicators are reasonably obvious measures of the economic effects of exits, but do they lead to the same characterization? We could expect that countries that suffer from a severe depreciation would also undergo a deep recession, but there is no general theory that predicts a tight relationship between these two variables. Figure 1 displays the situation for all 57 cases in our sample. The correlation coefficient is 0.156 , suggesting

\footnotetext{
${ }^{5}$ There remains another sample selection problem as we restrict our attention to pegged regime cases. A solution would be to adopt a three-step procedure, the first step involving the choice of a pegged regime against the floating alternative. This is left for further research.

${ }^{6}$ We define $e$ as the amount of anchor currency for one unit of domestic currency so that $y_{i, t}>0$ corresponds to an appreciation of the domestic currency.

${ }^{7}$ Since output gaps are measured at the annual frequency, we actually use the change in the output gap between year $t-1$ and year $t+1$, where $t$ is the year of exit.
} 
some limited commonality. ${ }^{8}$ Thus, we do not expect that the two different indicators of the economic effects of exits will lead to the same results.

Figure 1 about here

\subsection{Orderly vs. Disorderly Exits}

The literature so far has transformed an exchange rate indicator such as $(6)$ into a $(0,1)$ indicator, which allows for a sharp distinction between orderly and disorderly exits. Duttagupta and Otker-Robe (2003) and Aşıcı and Wyplosz (2003) define orderly exits as those where the exchange rate does not crash within a given period following the exit decision. More precisely, they replace $y_{i, t}$ in (1) with $\widetilde{y}_{i . t}$ defined as:

$$
\text { Orderly exit: } \quad \tilde{y}_{i, t}=1 \quad \text { iff } y_{i, t} \leq \bar{y}
$$

$$
\text { Disorderly exit: } \quad \tilde{y}_{i, t}=0 \quad \text { iff } y_{i, t}>\bar{y}
$$

and treat the regression as censored. ${ }^{9}$ Detragiache et al. (2005) use a different rule; they identify disorderly exits as those where the new regime is identified as "freely falling" in Reinhart and Rogoff (2004) classification.

A natural preliminary question is whether such a clear-cut separation is compatible with the data. The underlying hypothesis is that orderly and disorderly exits belong to different samples. This hypothesis can be tested for the two indicators of the economic effect of exiting - the exchange rate and output - by determining whether their distributions are bimodal, or even multimodal, as a first step towards determining a separating criterion.

For all exit cases, excluding the outlier for Iraq (January 1981) with a 58\% decline in the output gap, Figure 2 shows the kernel density estimates of the observed distributions of both indicators, the change in the exchange rate and the change in the output gap. Visual inspection suggests the presence of two modes (local maxima) for the exchange rate indicator and of one mode for the output indicator. ${ }^{10}$ These observations are confirmed by Silverman's test (1981), which tends to reveal one mode for the change in the output gap and fails to reject the presence of two modes for the change in the exchange rate. But the left-most mode for the exchange rate indicator, which could correspond to disorderly

\footnotetext{
${ }^{8}$ Excluding the output gap outlier (the output gap declined by $58 \%$ of potential GDP in Iraq in January 1981), the correlation coefficient rises to 0.301 .

${ }^{9}$ In the former, the empirical criterion for an orderly exit is an exchange rate depreciation of less than two standard errors of post-exit exchange rate changes within the sample of all exit cases; in the latter it is a depreciation of less than $25 \%$, with some sensitivity tests regarding the threshold.

${ }^{10}$ The figure also reveals that the normality assumption used in the Heckman procedure is unlikely to be satisfied. This must be kept in mind in interpreting the results below. Note however that eliminating one outlier for the output gap indicator delivers a near-normal estimated kernel density.
} 
exits, is located in the tails and is statistically negligible compared to the major peak, hence only few observations are concentrated around that mode.

Figure 2 about here

Another way of checking whether the separation between orderly and disorderly exits is justified is to use the non-parametric Kolmogorov-Smirnov and Kruskal-Wallis tests that ask whether two populations are drawn from distinct statistic distributions. ${ }^{11}$ For the classification procedure (8), we cannot apply the test directly to, say, the exchange rate indicator on the basis of a classification into orderly and disorderly exits based on this same indicator because $y_{i, t}$ is truncated within each category $\tilde{y}_{i, t}=0,1$. One possibility is to examine the output gap change observations (7) using a sample partition based on the exchange rate indicator (6) and, conversely, to examine the exchange rate indicator (6) on a partition determined by the output gap measure (7). Another possibility is to use the classification adopted by Detragiache et al. (2005) who consider disorderly exits as those for which the post-exit regime is the "freely-falling exchange rate" category identified by R\&R.

Table 2 shows the corresponding results. The first three rows in the upper part show the p-values for the hypothesis that the distribution of exchange rate changes does not differ across orderly and disorderly exits, where orderly exits correspond to a fall in the output gap of less than 0,3 or $5 \%$, respectively. The next three rows test for different distributions of the change in the output gap for orderly and disorderly exits where orderly exits correspond to an exchange rate depreciation of less than $15 \%, 25 \%$, and $40 \%$, respectively. The last two rows show the tests when we use the Detragiache et al. (2005) classification. When the exchange rate is used as the criterion, we can generally reject the hypothesis that the output gap distributions are the same for orderly and disorderly exists. However, this conclusion does not carry through to R\&R's related "freely falling" category. Conversely, the output gap criterion does not separate the exchange rate distributions, except for the most severe criterion $(-5 \%)$. The fact that the distributions of exchange rate changes are different with the Detragiache et al. (2005) criterion is nearly tautological as the partition is based on inflation and the exchange rate itself, which are typically highly correlated when both move fast.

Table 2 about here

These observations suggest that separating a priori the sample of exits into two groups, as is done on much of the literature, is not justified. They cast doubt on the practice of using as right hand-side variable in (1) a binary indicator of the effect of exits. It is also unnecessary. Instead of explaining orderly vs. disorderly exits, we can explain what happens to the exchange rate and to the output gap at the time of exit. Using the exchange rate and output change variables themselves rather than grouping them into two arbitrary categories should be at least as informative.

\footnotetext{
${ }^{11}$ The Kolmogorov-Smirnov test is based on the distance between the histograms of the two populations. The Kruskal-Wallis test is based on the medians of the populations.
} 


\section{Explanatory Variables}

The issue at hand lies at the intersection of two rich bodies of literature: the choice of an exchange regime and currency crises. The first body matters in the sense that exits can be seen as a voluntary decision to adopt a new regime that has become desirable either because conditions have changed or because the previous choice was ill-informed. The second body of literature is of interest in those cases where exits are involuntary, when speculative attacks force the monetary authorities to adopt another regime, typically a more flexible one. These interpretations are not mutually exclusive; an involuntary exit may reflect changing conditions or an earlier mistaken choice.

\subsection{Choice of an exchange regime}

Two approaches are relevant. The first one is the Optimum Currency Area (OCA) theory; the second is the use of an exchange rate anchor to achieve greater credibility. The OCA theory asks under which conditions it is desirable to peg the exchange rate. ${ }^{12}$ Its starting point is that the decision to adopt a pegged regime amounts to giving up the use of monetary policy, hence a trade-off between the benefits of a peg and the cost of losing a policy instrument.

Note that this conclusion applies when capital is freely mobile; in the presence of effective capital controls, monetary policy may retain some usefulness. ${ }^{13}$ Thus the relevant choice is not just about an exchange rate regime, but between the combination of exchange rate and capital mobility regimes. This observation suggests using an indicator of capital controls in explaining both the decision to exit and whether the exit is orderly. To the extent that they limit speculative pressure, we expect controls to ease up the impact of exits. The expected effect of capital controls on the decision to exit is ambiguous, however. On the one hand, capital controls enhance the desirability of adopting a pegged regime since they reduce its cost (the loss of the monetary policy instrument) and enhance the ability to defend it if they are effective in limiting speculative pressure. This would make exits less likely. On the other hand, the ability to continue using monetary policy is highly restricted and can easily be overestimated. The evidence is that controls are often used to conduct undisciplined policies and to maintain for too long an overvalued exchange rate, ${ }^{14}$ which raises the probability of exits, as opposed to timely realignments (Edwards, 1996).

The key message from the OCA theory is that a pegged regime is more desirable the higher is the degree of trade integration, but harder to sustain when the economy is subject to frequent and large real shocks, unless prices and wages are flexible and/or labor moves freely across borders. Given that prices and wages tend to be rigid in most

\footnotetext{
${ }^{12}$ The OCA theory considers a permanent peg in the form of adopting a foreign currency. The analysis is widely used to also characterize the desirably of softer currency pegs.

${ }^{13}$ The literature on the role and effectiveness is huge. For a recent survey, see Ariyoshi et al. (2000).

${ }^{14}$ See, e.g. Wyplosz (2002).
} 
countries and that international labor mobility remains too marginal to cope with repeated shocks, the OCA theory is implemented here by looking at the role of trade openness, possibly at trade intensity with the anchor currency country, and the size of real shocks, usually captured by the volatility of the terms of trade. These variables are consistently found to affect the exchange regime choice as predicted by theory (Klein and Marion, 1994; Edwards, 1996; Frieden et al., 2000; Levy-Yeyati et al., 2004). In addition, large countries may be seen as optimum currency area in and by themselves, and thus likely not to be interested in adopting a pegged regime. Size can be understood as economic and measured by the $G D P$, or geographical and measured by the area.

\subsection{Credibility}

The original OCA theory implicitly assumes that exchange rate stability is desirable but does not state explicitly why it is so. One possible reason is that a fixed exchange rate provides an anchor for the conduct of monetary policy. This can be seen as an implication of the result that the monetary policy instrument is lost in the presence of full capital mobility. What makes the adoption of a peg more desirable than other monetary policy strategies is the assumption that the monetary authorities are not benevolent or are subject to non-benevolent influences so that monetary policy faces an inflation bias. ${ }^{15}$ In that case, eliminating monetary policy discretion by committing to a fixed exchange rate may eliminate the inflation bias. It remains to be seen whether the exchange rate constraint is effectively taken into account by the monetary authorities; if it is not, monetary policy may be inflationary, which will lead to overvaluation and threaten the peg.

The empirical literature has followed this lead. A first set of studies examine the role of inflation. They report that the higher is inflation the less likely is the country to adopt or maintain a pegged regime (e.g. Edwards, 1996). Husain et al. (2004) find that, ceteris paribus, developing countries with limited capital mobility exhibit relatively low inflation and tend to adopt and maintain pegged regimes. Others introduce various measures of the quality of political governance. They typically confirm that poor quality of institutions make a pegged regime unlikely to survive (e.g. Alesina and Wagner, 2003: Levy-Yeyati et al., 2004). ${ }^{16}$ The budget deficit or the accumulated debt can also be seen as an indicator of the quality of economic governance, although these variables are rarely reported in the literature.

\subsection{Currency Crises}

One thing is to choose an exchange rate regime, it is quite another to sustain it. Currency crises can play havoc with all exchange rate regimes for a variety of reasons that have been formalized in three "generations" of crisis models. ${ }^{17}$

\footnotetext{
15 The seminal reference is Kydland and Prescott (1977). The application to the choice of an exchange regime is clearly spelled out in Giavazzi and Pagano (1998).

${ }^{16}$ For a more nuanced view informed by the Latin American case, see Frieden et al. (2000).

${ }^{17}$ Bubula and Otker-Robe (2003) report that all exchange regime are crisis prone, but the risks are higher with intermediate regimes, i.e. neither free floats nor hard pegs (currency board and dollarization).
} 
The first generation crisis theory focuses on macroeconomic policies that are inconsistent with the exchange rate commitment. This means looking at fiscal balances and at monetary policy and inflation as potential root causes of crises. Symptoms of inconsistency are likely to be found in exchange rate overvaluation and current account deficits. In addition, the literature on push-pull sources of capital flows (Calvo, Leiderman and Reinhart, 1996; Hausmann and Rojas-Suarez, 1996) suggests that changes in interest rates in worldwide financial markets may trigger damaging capital outflows.

The second generation crisis theory points to domestic economic or political vulnerabilities that may discourage authorities from upholding a pegged regime, especially in front of speculative activity. The literature has focused on unemployment, large and negative output gaps as well as political factors such as upcoming elections, weak governments, possibly non-democratic or corrupt regimes. ${ }^{18}$

The third generation crisis theory identifies financial maturity and currency mismatches as a source of vulnerability. Chang and Velasco (2000) note that a free float is a way of avoiding this variety of crises, which suggests that financial imbalances may lie behind exits from pegged regimes. This includes the degree of dollarization liability, which is indeed found by Levy-Yeyati et al. (2004) to reduce the odds of maintaining a pegged regime and the size of the external debt..$^{19}$ More generally, a repressed domestic financial system shuts down many of the channels that are mobilized during a currency crisis, which may be accompanied by a banking crisis as described in Kaminsky and Reinhart (1999). A contrario, the reasoning suggests that factors of domestic financial developments may heighten the risk of crises: we use as indicators the money supply, the liquidity of banking sector, and the size of private and total banking credit.

\subsection{Definition of Variables}

Use of Heckman's sample selection model requires the estimation of two equations: an exit equation and an exit effect equation. The literature review presented above has identified a number of variables that have been found to be relevant, both theoretically and empirically, to the choice of an exchange rate regime. In the absence of a more precise theory on exits and their aftermath, we experiment with these variables in both equations. ${ }^{20}$ The rationale is that exits can be seen as either the response to changing conditions that affect the optimal exchange rate regime or as the correction of a previously misguided choice. In that case, exits are likely to have reasonably effects; failure to respect these conditions, we hypothesize, could result in adverse effects in the form of large depreciations and/or output contraction.

\footnotetext{
${ }^{18}$ Supporting evidence of the role of political factors is provided by Alesina and Wagner (2003), Frieden et al. (2000) and Levy-Yeyati et al. (2004).

${ }^{19}$ The literature on the original sin (Eichengreen and Hausmann, 2003) suggests that what matters most is external debt issued in foreign currency. Data availability prevents us from using this important distinction.

${ }^{20}$ Identification does not strictly require that the set $X$ of explanatory variables appearing in (1) be a subset of the set W in (2). Still, as argued in Wooldridge (2002), it is preferable that this be the case to avoid collinearity problems in the main equation.
} 
We are restricted by the availability of data, especially for our sample of developing countries. Ideally we want to use monthly data but some only exist at the annual frequency. This will affect the way we construct them. In addition, we face a potential endogeneity problem. For instance, high inflation may lead to a disorderly exit but, as reported by Husain et al. (2004) pegged rates are found to deliver low inflation. We deal with the issue by using all explanatory variables as lags. Data available at the monthly frequency are observed as averages or changes between month $t-13$ and month $t-1$ where $t$ is the month of exit when these are flow data and on month $\mathrm{t}-1$ when they are stocks. Data available at the annual frequency are observed over the previous calendar year. The Data Appendix lists all the variables and their sources.

\section{Results}

\subsection{Exchange Rate}

We first consider the nominal exchange rate indicator (6), defined such that a decrease represents a depreciation. The dependent variable for the exit cases is seen in Figure 1 and Table 3 provides some descriptive statistics, which indicate that exits tend to be accompanied by unusual depreciations. Formal tests confirm that the exit and non-exit samples are drawn from different distributions.

Table 4 presents the regression results, including robust z-statistics. To reduce the risk of simultaneity bias, all the right-hand side variables are lagged, corresponding to the oneyear period that precedes exit. For each specification, we report three regressions: the first two ones use Heckman's sample selection model, first using a maximum likelihood estimator - column ML - and then a two-step estimator; the last column displays the OLS regression, as an indication of the sample bias effect. Moving down, the table first displays the main equation (5), then the selection equation (2) and, finally a battery of statistics. Of crucial importance is whether sample selection is indeed a source of bias and whether the estimation procedure is effective at removing the bias. With the ML estimator, this is the case when we cannot reject the assumption that the correlation between the error terms in the selection and main equations, $\rho$ in (3), is significantly different from zero. The tests indicate that the hypothesis that $\rho=0$ can be rejected at a high confidence level. The two-step procedure directly estimates Mill's ratio $\lambda$ in (5), which is reported along with its z-statistics. Here again, we can safely reject the null $\lambda=$ 0 . For the OLS regression we only display the adjusted $\mathrm{R}^{2}$.

The explanatory variables included in our benchmark equation are robust to specification searches. The selection equation is shown in the lower part of the table. The dependent variable takes the value of 1 when the country exits, 0 when the existing pegged regime is remained. Quite reasonably, an exit is found to be more likely when foreign exchange rate reserves have been declining, when the exchange rate has been overvalued, when the terms of trade and investment have been volatile. Capital controls raise the probability of exit. Large countries, measured by the GDP, are more likely to exit than smaller ones. ${ }^{21}$

\footnotetext{
${ }^{21}$ We also experimented with geographical size, but this variable was not found to be significant.
} 
Surprisingly perhaps, booming conditions increase the probability of exit, while a low level of liquidity, measured by the M2/GDP ratio, makes the exit less likely. High foreign direct investments make an exit more likely, presumably because the herald a sudden stop, see Calvo et al. (1996). Finally, an exit is more likely when other countries have exited over the previous twelve months.

The main equation's dependent variable is the change in the exchange rate. In what follows, we interpret the results by considering that the larger is the depreciation - the more negative is the dependent variable - the more painful is the exit. As initially argued by Eichengreen and Masson (1998), a clear result is that it is better to exit early than too late: overvaluation and declining reserves all contributes to a painful exit.

Macroeconomic conditions also shape the ease of exit: quickly rising money supply, high inflation and a recession (a low output gap) result in a falling exchange rate. The exit is also more painful when the US interest rate is rising, a clear support for the push-pull view put forward by Hausmann and Rojas-Suarez (1996). Finally, capital controls, which have been found here and in Edwards (1996) to make an exit more likely, also make it more benign; the latest result stands in contrast with recent works that argue that capital controls are not effective. ${ }^{22}$

The remaining estimates presented in Table 4 involve some variables which have been found significant in the main equation, but not systematically so. Larger foreign investment and more openness to trade tend to help when exiting. Surprisingly, the view that a solid fiscal position is desirable at the time of exit, presumably to reassure the markets, is only weakly supported by the data. The OCA theory argues that tighter integration with the anchor currency country underpins a pegged regime. We looked at the share of exports going to the anchor currency country, found no significant effect in the selection (exit) equation and a weak tendency to make exit easier but only in the case of developed countries.

The usual "dog that did not bark" observation is in order. Among the variables that we collected on the basis of the literature surveyed in Section 4 and that were never found to be significant in our estimations we find the current account, both in level and in change, country size and various measures of terms of trade level.

Table 4 about here

\subsection{Output Gap}

Our alternative criterion of exit success is the change in the output gap (7): a successful or orderly exit is not accompanied by a sharp fall in the output gap. From Figure 1, we anticipate that the main equation will be different from what has been found with the exchange rate indicator, and this is indeed partly the case. On the other side, the selection equation should remain reasonably unchanged since it only differs because of small

${ }^{22}$ Ariyoshi et al. (2000) present a survey of the literature. 
variations in the sample and because of system estimation in the ML case. The results are shown in Table 5, which is patterned after Table 4.

Although the role of overvaluation is not robust, it remains the case that early exits are found to be easier, witness the adverse impact of a long period of pegging. Capital controls, foreign direct investment and openness are also again found to be positive factors for a smooth exit. The loss of foreign exchange reserves and inflation do not seem to matter for the output criterion, in contrast with the exchange rate criterion. While a previously improving output gap has been found to support the exchange rate at the time of exit, it has the opposite effect on output, suggesting a boom-and-bust effect, as previously described in Wyplosz (2002). Surprisingly, easy financial conditions - a highly liquid banking system, large foreign direct investments, rising credit to the public sector and, although less robust, an increase in the real money supply - ease the exit process. $^{23}$

Table 5 about here

Perhaps of as much interest are the variables that have been found not be significant: the budget balance (though we found some support that deteriorating budgetary situation increases the probability of exit), the concentration of trade with the anchor currency country, the current account balance and foreign indebtedness (except maybe for the public debt in the case of developed countries). Neither did we find evidence that GDP per capita, which Alesina and Wagner (2003) see as a reasonable proxy for the quality of institutions, affect the probability of exit and the outcome of exit.

\subsection{Sensitivity Analysis}

As previously acknowledged, the two-way classification of exchange rate regimes is unavoidably arbitrary. We have therefore experimented with four alternative classifications presented in Table 1 . Alternative 1 eliminates the category "freely falling exchange rates" that R\&R further subdivide in their categories. This alternative therefore treats freely falling exchange rates as sui generis. Alternative 2 follows the opposite logic adopted by Detragiache et al. (2005) who consider that exit occurs when a country leave a peg to move to the freely falling category and also take a more restrictive definition of fixed exchange regimes, excluding R\&R's categories 9 to 11, i.e. various forms of crawling bands. Yet, in a sensitivity test, Detragiache et al. (2005) allow for these crawling bands to be classified as pegs, and this is our Alternative 3. Finally, we adopt the classification of Bubula and Otker-Robe (2002), which is not based on the R\&R algorithm nor on the de jure IMF definition, but on their own de facto classification based on IMF documents and analysis of exchange rate behavior; this is Alternative 4.

The results are displayed in Table 6 for the exchange rate equation and in Table 7 for the output gap equation. One way of looking at the table is as an indication of the proper definition of exchange rate regimes, assuming that the benchmark equations - reported

\footnotetext{
${ }^{23}$ Gupta et al. (2003) examine the factors that affect output during the currency crises. They too find that a loose monetary policy help during the post-crisis period.
} 
again here - are properly specified. We focus on the selection equation, where the dependent variable is the probability of exiting a pegged regime. Alternative 2, proposed by Detriagache et al. (2005), which has a narrow definition of pegged regimes, appears as unsatisfactory as does to a lesser extent Alternative 1, which ignores the freely falling exchange rate case.

An alternative reading of these results is to accept that each alternative is plausible and ask which of the explanatory variables are robust in the sense that the sign, size and significance of their coefficients remain reasonably unchanged. We focus on the main equations. When the exchange rate change is the dependent variable (Table 6), this is the case of overvaluation, changes in the US interest rate, changes in money supply and capital controls. Inflation and the output gap are less robust and the change in gross reserves appears not to be robust. For the output gap equation (Table 7), the lagged gap, duration of the pegged regime, bank liquidity, capital controls and foreign direct investment are robust. The roles of openness and credit to the public sector are not confirmed.

Table 6 and Table 7 about here

\subsection{Orderly vs. Disorderly Exits}

We have previously concluded that the distinction between orderly and disorderly, and therefore the use of binary indices instead of the evolution of the exchange rate and of the output gap is not justified by the data. However, since this is the way adopted by the literature so far, for the sake of comparison we present here estimates of the bivariate probit model (8), where the dependent variable takes the value of 1 if the exit is deemed orderly and 0 for disorderly exits.

The bivariate probit regressions presented in Table 8, where orderly exits are defined as an exchange rate decline of less than $25 \%,{ }^{24}$ use Heckman's sample selection model, using a maximum likelihood estimator. The partition is shown in Appendix Table A4. The first column corresponds to the same specification as the benchmark regression shown in Table 4. Unsurprisingly, the results are not satisfactory; in particular we cannot reject the null that the error terms of main and selection equations are uncorrelated, i.e. the sample selection bias is not appropriately treated. The next two columns present alternative specifications where the sample selection treatment is effective. Of the previously significant variables, only two survive: both overvaluation and an increase in US interest rates reduce the probability that the exit is orderly. We also find that the probability of orderly exit increases with the current account and the size of bank credit. Interestingly, we find that this is also the case when the pre-exit de jure exchange regime is explicitly fixed. This suggests that there exist interesting links between the de jure and de facto regimes, along the lines of "fear of fixing" and "fear of pegging", that Genberg and Swoboda (2005) have recently started to investigate.

\footnotetext{
${ }^{24}$ Frankel and Rose (1996) have introduced the widely used 25\% threshold.
} 
Table 9 presents similar results where an orderly exit is defined as an exit that is accompanied by an output gap decline of less than 3\%. Along with alternative specifications shown in the last three columns, we find support for the view that the following variables increase the odds of an orderly exit, conditional on the decision of exiting a peg arrangement: the presence of capital controls, financial development (measure by the M2/GDP ratio), bank liquidity and trade openness. On the higher side, a long duration of pegging and a booming economy increase the odds of a disorderly exit.

Table 8 and Table 9 about here

\section{Conclusions}

This paper revisits a small and growing literature on exits from pegged exchange rate regimes. This literature has tended to draw a sharp distinction between orderly and disorderly exits. We find that this distinction is not supported by two indicators of postexit performance, the exchange rate and the output gap. As a consequence, we focus on the evolution of these indicators rather than adopting probit or logit procedure.

Some previous work also overlooks a potentially serious sample selection problem. In this study we adopt Heckman's sample selection model and find, indeed, that the sample selection problem is present. To the extent that this model adequately corrects for the associated bias, our results are therefore more reliable. Our extensive sensitivity tests provide reassurance that the results are fairly robust.

A byproduct of the Heckman model is that we estimate both the probability of exit and the post-exit performance of the economy. Table 10 summarizes our findings. They are in line with the literature surveyed in Section 4 in the sense that the variables found to be significant and their effects can be explained by existing theories. Yet, these theories are not fully vindicated, for many variables that we would expect to find are not, in fact, statistically significant. This is particularly the case of those that emphasize the desirability of macroeconomic discipline, especially the current account and the budget balance. Note also the ubiquitous role of capital controls: they make exits more likely but less threatening, providing support to both sides of the debate on their usefulness.

Many countries follow a progressive process, gradually increasing the degree of exchange rate flexibility. We have limited our study to one-shot depegging, in effect eliminating this important consideration. Duttagupta et al. (2004) offer an analysis based on case studies. 


\section{References}

Agénor, Pierre-Richard (2004) "Orderly Exits from Adjustable Pegs and Exchange Rate Bands, Policy Issues and the Role of Capital Flows", unpublished paper, The World Bank.

Alesina, Alberto and Alexander Wagner (2003) "Choosing (and Reneging on) Exchange Rate Regimes”, unpublished, Harvard University.

Ariyoshi, Akira, Karl Habermeier, Bernard Laurens, Inci Otker-Robe, Jorge Iván, Canales-Kriljenko and Andrei Kirilenko (2000) "Capital Controls: Country Experiences with Their Use and Liberalization”, Occasional Paper 190, International Monetary Fund.

Aş1c1, Ahmet Atıl and Charles Wyplosz (2003) “The Art of Gracefully Exiting a Peg”, The Economic and Social Review, 34(3): 211-28.

Bubula, Andrea and Inci Otker-Robe (2002) "The Evolution of Exchange Rate Regimes Since 1990: Evidence from De Facto Policies”, IMF Working Paper WP/02/155.

Chang, Roberto and Andres Velasco (2000) "Financial Fragility and the Exchange Rate Regime", Journal of Economic Theory 92(1): 1-34.

Calvo, Guillermo, Leonardo Leiderman and Carmen Reinhart (1996) "Inflows of Capital to Developing Countries in the 1990s", Journal of Economic Perspectives 10(2), Spring, pp. 123-39.

Detragiache, Enrica, Ashoka Mody and Eisuke Okada (2005) "Exits from Heavily Managed Exchange Rate Regimes", IMF Working Paper "P/05/39.

Duttagupta, Rupa and Inci Otker-Robe (2003) "Exits from Pegged Regimes: An Empirical Analysis", IMF Working Paper WP/03/147.

Duttagupta, Rupa, Gilda Fernandez and Cem Karacadag (2004) "From Fixed to Float: Operational Aspects of Moving Toward Exchange Rate Flexibility“, IMF Working Paper $\mathrm{WP} / 04 / 126$.

Edwards, Sebastian (1996) "The Determinants of the Choice Between Fixed and Flexible Exchange Rate Regimes”, NBER Working Paper 5756.

Edwards, Sebastian and Igal Magendzo (2003) “A Currency of One’s Own? An Empirical Investigation on Dollarization and Independent Currency Unions", National Bureau of Economic Research Working Paper No. 9514.

Eichengreen, Barry (1994) International Monetary Arrangements for the 21 st Century, Washington: Brookings Institution. 
Eichengreen, Barry and Paul Masson (1998) "Exit Strategies: Policy Options for Countries Seeking Greater Exchange Rate Flexibility”, IMF Occasional Paper 168.

Eichengreen, Barry and Ricardo Hausmann (2003) "Original Sin: The Road to Redemption", in: B. Eichengreen and R. Hausmann (eds), Debt Denomination and Financial Instability in Emerging Market Economics.

Fischer, Stanley (2001) “Exchange Rate Regimes: Is the Bipolar View Correct?", Journal of Economic Perspectives 15(2): 3-24.

Frankel, Jeffrey and Andrew Rose (1996) "Currency Crashes in Emerging Markets: An Empirical Treatment", Journal of International Economics 41: 351-66.

Frieden, Jeffry, Piero Ghezzo and Ernesto Stein (2000) "Politics and Exchange Rates: A Cross-Country Approach to Latin America”, Inter-American Development Bank Working Paper R-421.

Genberg, Hans and Alexander Swoboda (2005) "Exchange-Rate Regimes: Does What Countries Say Matter?", unpublished paper, Graduate Institute of International Economics, Geneva.

Ghosh, Atish, Anne-Marie Gulde, and Holger C. Wolf (2003) Exchange Rate Regime: Choices and Consequences, Cambridge: MIT Press.

Giavazzi, Francesco and Marco Pagano (1988) "The Advantage of Tying One's Hands", European Economic Review 32:(5): 1055-75.

Gupta, Poonam, Deepak Mishra, and Ratna Sahay (2003) "The Output Response to Currency Crises", IMF Working Paper WP/03/230.

Hausmann, Ricardo and Liliana Rojas-Suarez (eds) (1996) Volatile Capital Flows: Taming their Impact on Latin America, Baltimore: Johns Hopkins University Press.

Heckman, James J. (1979) "Sample Selection Bias as a Specification Error", Econometrica 47:153-161.

Husain, Aasim M., Ashoka Mody and Kenneth S. Rogoff (2004) "Exchange Rate Regime Durability and Performance in Developing Versus Advanced Economies", National Bureau of Economic Research Working Paper No. 10869.

Kaminsky, Graciela and Carmen Reinhart (1998) "Leading Indicators of Currency Crises", IMF Staff Papers 45(1): 1-48.

Kaminsky, Graciela and Carmen Reinhart (1999) "The Twin Crises: The Causes of Banking and Balance-of-Payments Problems", American Economic Review 89(3): 473500 . 
Klein, Michael and Nancy Marion (1997) "Explaining the Duration of Exchange Rate Pegs", Journal of Development Economics 54(2): 387-404.

Kydland, Finn and Edward Prescott (1977) "Rules Rather than Discretion: The Inconsistency of Optimal Plans”, Journal of Political Economy 85: 473-492.

Levy-Yeyati, Eduardo and Federico Sturzenegger (2005) "Classifying Exchange Rate Regimes: Deeds vs. Words”, European Economic Review, forthcoming.

Levy-Yeyati, Eduardo, Federico Sturzenegger and Iliana Reggio (2004) "On the Endogeneity of Exchange Rate Regimes”, unpublished, University Torcuato Di Tella.

Masson, Paul and Francisco Ruge-Murcia (2003) "Explaining the Transition between Exchange Rate Regimes", unpublished paper, University of Montreal.

Rebelo, Sergio and Carlos Végh (2002) "When Is It Optimal to Abandon a Fixed Exchange Rate?”, unpublished paper, University of California at Los Angeles.

Reinhart, Carmen and Kenneth Rogoff (2004) "The Modern History of Exchange Rate Arrangements: A Reinterpretation”, Quarterly Journal of Economics 119 (1): 1-48.

Silverman, B.W. (1981) “Using Kernel Density Estimates to Investigate Multimodality”, Journal of the Royal Statistical Society B 43: 97-99.

Wooldridge, Jeffrey (2002) Econometric Analysis of Cross Section and Panel Data, Cambridge: MIT Press.

Wyplosz, Charles (2002) "How Risky is Financial Liberalization in the Developing Countries?", Comparative Economic Studies 44(2-3): 1-26. 
Table 1. Exchange Rate regimes

\begin{tabular}{|c|c|c|c|c|c|c|}
\hline \multirow[b]{2}{*}{$\mathrm{R} \& \mathrm{R}$ categories } & \multirow[b]{2}{*}{$\begin{array}{l}\text { R\&R four-way } \\
\text { classification }\end{array}$} & \multicolumn{5}{|c|}{ Two-way classifications } \\
\hline & & Benchmark & Alternative 1 & $\begin{array}{l}\text { Alternative } 2 \\
\text { (Detragiache, } \\
\text { 2005) }\end{array}$ & $\begin{array}{l}\text { Alternative } 3 \\
\text { (Detragiache, } \\
\text { 2005) }\end{array}$ & $\begin{array}{l}\text { Alternative } 4 \\
\text { Bubula et al. } \\
(2003)\end{array}$ \\
\hline 1. No separate currency & Peg & Fixed & Fixed & Fixed & Fixed & Fixed \\
\hline $\begin{array}{l}\text { 2. Pre announced peg or } \\
\text { currency board }\end{array}$ & Peg & Fixed & Fixed & Fixed & Fixed & Fixed \\
\hline $\begin{array}{l}\text { 3. Pre announced } \\
\text { horizontal band } \leq 2 \%\end{array}$ & Peg & Fixed & Fixed & Fixed & Fixed & Fixed \\
\hline 4. De facto peg & Peg & Fixed & Fixed & Fixed & Fixed & Fixed \\
\hline $\begin{array}{l}\text { 5. Pre announced crawling } \\
\text { peg }\end{array}$ & Limited flexibility & Fixed & Fixed & Fixed & Fixed & Fixed \\
\hline $\begin{array}{l}\text { 6. Pre announced crawling } \\
\text { band } \leq 2 \%\end{array}$ & Limited flexibility & Fixed & Fixed & Fixed & Fixed & Fixed \\
\hline 7. De facto crawling peg & Limited flexibility & Fixed & Fixed & Fixed & Fixed & Fixed \\
\hline $\begin{array}{l}\text { 8. De facto crawling band } \\
\leq 2 \%\end{array}$ & Limited flexibility & Fixed & Fixed & Fixed & Fixed & Fixed \\
\hline $\begin{array}{l}\text { 9. Pre announced crawling } \\
\text { band } \geq 2 \%\end{array}$ & Limited flexibility & Fixed & Fixed & Float & Fixed & Fixed \\
\hline $\begin{array}{l}\text { 10. De facto crawling band } \\
\leq 5 \%\end{array}$ & Managed float & Fixed & Fixed & Float & Fixed & Fixed \\
\hline 11. Moving band $\leq 2 \%$ & Managed float & Fixed & Fixed & Float & Fixed & Fixed \\
\hline 12. Managed floating & Managed float & Float & Float & Float & Float & Float \\
\hline 13. Freely floating & Float & Float & Float & Float & Float & Float \\
\hline 14. Freely falling (1-11) & Fixed & Fixed & Ignored & Float & Float & Absent \\
\hline 14. Freely falling (12-13) & Float & Float & Ignored & Float & Float & Absent \\
\hline
\end{tabular}


Table 2. Tests of the Orderly vs. Disorderly Classification

( $p$ value for rejecting the hypothesis of identical distributions)

\begin{tabular}{lcccc}
\hline Classification based on & Threshold & Variable & Kolmogorov-Smirnov & Kruskal-Wallis \\
\hline Output gap & $0 \%$ & Exchange rate & 0.954 & 0.942 \\
& $-3 \%$ & Exchange rate & 0.088 & 0.051 \\
& $-5 \%$ & Exchange rate & 0.002 & 0.005 \\
Exchange rate depreciation & $15 \%$ & Output gap & 0.078 & 0.216 \\
& $25 \%$ & Output gap & 0.000 & 0.003 \\
& $40 \%$ & Output gap & 0.001 & 0.018 \\
Detragiache et al. (2005) & & & & 0.002 \\
& R\&R & Exchange rate & 0.021 & 0.178 \\
\hline
\end{tabular}

Table 3. Endogenous Variables

\begin{tabular}{llcc}
\hline $\begin{array}{l}\text { Type of } \\
\text { event }\end{array}$ & & $\begin{array}{l}\text { Change in nominal exchange rate (\%) } \\
\text { between months } \mathrm{t}-6 \text { and } \mathrm{t}+6\end{array}$ & $\begin{array}{l}\text { Change in output gap (\%) } \\
\text { between year } \mathrm{t}-1 \text { and } \mathrm{t}+1\end{array}$ \\
\hline Exits & Median & -44.74 & -4.56 \\
& Average & -73.16 & -6.20 \\
& St. Dev. & 81.92 & 9.71 \\
\multirow{2}{*}{ Non exits } & Median & -1.32 & 0.77 \\
& Average & -3.03 & 0.70 \\
& St. Dev. & -14.73 & 6.09 \\
\hline
\end{tabular}


Table 4. The Exchange Rate

\begin{tabular}{|c|c|c|c|c|c|c|c|c|c|c|c|c|c|c|c|}
\hline \multirow[b]{2}{*}{ Change in exchange rate } & \multicolumn{3}{|c|}{ Benchmark } & \multicolumn{3}{|c|}{1} & \multicolumn{3}{|c|}{2} & \multicolumn{3}{|c|}{3} & \multicolumn{3}{|c|}{4} \\
\hline & $\overline{\mathrm{ML}}$ & Two-steps & OLS & $\overline{\mathrm{ML}}$ & Two-steps & OLS & $\overline{\mathrm{ML}}$ & Two-steps & OLS & $\overline{\mathrm{ML}}$ & Two-steps & 5 OLS & $\overline{\mathrm{ML}}$ & Two-steps & OLS \\
\hline Inflation & $\begin{array}{l}-1.771 * * * \\
{[3.18]}\end{array}$ & $\begin{array}{l}-1.811^{* *} \\
{[2.54]}\end{array}$ & $\begin{array}{l}-0.273 \\
{[0.63]}\end{array}$ & $\begin{array}{l}-1.660^{* * *} \\
{[3.14]}\end{array}$ & $\begin{array}{l}-1.718^{* *} \\
{[2.46]}\end{array}$ & $\begin{array}{l}-0.174 \\
{[0.38]}\end{array}$ & $\begin{array}{l}-1.684^{* * * *} \\
{[3.03]}\end{array}$ & $\begin{array}{l}-1.681^{* *} \\
{[2.39]}\end{array}$ & $\begin{array}{l}-0.325 \\
{[0.76]}\end{array}$ & $\begin{array}{l}-1.164^{* *} \\
{[2.22]}\end{array}$ & $\begin{array}{l}-1.178 \\
{[1.62]}\end{array}$ & $\begin{array}{l}-0.024 \\
{[0.06]}\end{array}$ & $\begin{array}{l}-0.767 \\
{[1.34]}\end{array}$ & $\begin{array}{l}-0.779 \\
{[1.02]}\end{array}$ & $\begin{array}{l}0.331 \\
{[0.81]}\end{array}$ \\
\hline Overvaluation & $\begin{array}{l}-2.817 * * * \\
{[3.43]}\end{array}$ & $\begin{array}{l}-3.055^{* * *} \\
{[3.35]}\end{array}$ & $\begin{array}{l}-4.312 * * * \\
{[5.46]}\end{array}$ & $\begin{array}{l}-2.476 \text { *** } \\
{[2.68]}\end{array}$ & $\begin{array}{l}-2.776^{* * *} \\
{[3.00]}\end{array}$ & $\begin{array}{l}-4.121^{* * * *} \\
{[5.15]}\end{array}$ & $\begin{array}{l}-2.919^{* * *} \\
{[3.66]}\end{array}$ & $\begin{array}{l}-3.187^{* * *} \\
{[3.56]}\end{array}$ & $\begin{array}{l}-4.315^{* * *} \\
{[5.35]}\end{array}$ & $\begin{array}{l}-3.557^{* * * *} \\
{[5.40]}\end{array}$ & $\begin{array}{l}-3.595^{* * *} \\
{[4.13]}\end{array}$ & $\begin{array}{l}-4.748^{* * *} \\
{[6.45]}\end{array}$ & $\begin{array}{l}-3.490^{* * *} \\
{[5.58]}\end{array}$ & $\begin{array}{l}-3.387^{* * *} \\
{[3.94]}\end{array}$ & $\begin{array}{l}-4.513^{* * *} \\
{[6.54]}\end{array}$ \\
\hline Output gap (lagged) & $\begin{array}{l}5.070^{* *} \\
{[2.41]}\end{array}$ & $\begin{array}{l}4.544 * * \\
{[2.51]}\end{array}$ & $\begin{array}{l}2.906 \\
{[1.36]}\end{array}$ & $\begin{array}{l}5.515^{* * *} \\
{[2.66]}\end{array}$ & $\begin{array}{l}4.944 * * * \\
{[2.72]}\end{array}$ & $\begin{array}{l}3.071 \\
{[1.42]}\end{array}$ & $\begin{array}{l}5.315^{* *} \\
{[2.43]}\end{array}$ & $\begin{array}{l}4.660^{* * *} \\
{[2.66]}\end{array}$ & $\begin{array}{l}3.340 \\
{[1.51]}\end{array}$ & $\begin{array}{l}4.715^{* *} \\
{[2.32]}\end{array}$ & $\begin{array}{l}4.650^{* * *} \\
{[2.66]}\end{array}$ & $\begin{array}{l}2.674 \\
{[1.33]}\end{array}$ & $\begin{array}{l}4.911 * * * \\
{[2.82]}\end{array}$ & $\begin{array}{l}5.189^{* * *} \\
{[2.99]}\end{array}$ & $\begin{array}{l}3.217 \\
{[1.55]}\end{array}$ \\
\hline Change in money supply (M2) & $\begin{array}{l}-1.147 * * * \\
{[3.12]}\end{array}$ & $\begin{array}{l}-1.031^{* *} \\
{[1.96]}\end{array}$ & $\begin{array}{l}-1.258^{* *} \\
{[2.48]}\end{array}$ & $\begin{array}{l}-1.225^{* * *} \\
{[3.32]}\end{array}$ & $\begin{array}{l}-1.081^{* *} \\
{[2.10]}\end{array}$ & $\begin{array}{l}-1.310^{* *} \\
{[2.38]}\end{array}$ & $\begin{array}{l}-1.062^{* * *} \\
{[3.11]}\end{array}$ & $\begin{array}{l}-0.996^{*} \\
{[1.91]}\end{array}$ & $\begin{array}{l}-1.148^{* *} \\
{[2.30]}\end{array}$ & $\begin{array}{l}-1.077^{* * *} \\
{[2.80]}\end{array}$ & $\begin{array}{l}-1.103^{* *} \\
{[2.21]}\end{array}$ & $\begin{array}{l}-1.253^{* *} \\
{[2.15]}\end{array}$ & $\begin{array}{l}-1.186^{* * *} \\
{[3.13]}\end{array}$ & $\begin{array}{l}-1.265^{* *} \\
{[2.55]}\end{array}$ & $\begin{array}{l}-1.432^{* *} \\
{[2.56]}\end{array}$ \\
\hline Change in US interest rate & $\begin{array}{l}-17.873^{* *} \\
{[2.11]}\end{array}$ & $\begin{array}{l}-18.660^{*} \\
{[1.89]}\end{array}$ & $\begin{array}{l}-6.359 \\
{[0.89]}\end{array}$ & $\begin{array}{l}-17.183 * * \\
{[2.05]}\end{array}$ & $\begin{array}{l}-17.823^{*} \\
{[1.85]}\end{array}$ & $\begin{array}{l}-5.996 \\
{[0.81]}\end{array}$ & $\begin{array}{l}-14.373 * \\
{[1.92]}\end{array}$ & $\begin{array}{l}-13.888 \\
{[1.38]}\end{array}$ & $\begin{array}{l}-1.727 \\
{[0.23]}\end{array}$ & $\begin{array}{l}-13.993^{*} \\
{[1.83]}\end{array}$ & $\begin{array}{l}-16.083 \\
{[1.63]}\end{array}$ & $\begin{array}{l}-6.142 \\
{[0.97]}\end{array}$ & $\begin{array}{l}-15.489^{* *} \\
{[2.14]}\end{array}$ & $\begin{array}{l}-18.247^{*} \\
{[1.90]}\end{array}$ & $\begin{array}{l}-9.858 \\
{[1.49]}\end{array}$ \\
\hline Capital controls & $\begin{array}{l}43.192 * * \\
{[2.02]}\end{array}$ & $\begin{array}{l}44.006^{* *} \\
{[2.13]}\end{array}$ & $\begin{array}{l}47.950^{*} \\
{[1.82]}\end{array}$ & $\begin{array}{l}54.622 * * \\
{[2.34]}\end{array}$ & $\begin{array}{l}52.466^{* *} \\
{[2.47]}\end{array}$ & $\begin{array}{l}54.690^{* *} \\
{[2.07]}\end{array}$ & $\begin{array}{l}43.096^{* *} \\
{[2.11]}\end{array}$ & $\begin{array}{l}44.792^{* *} \\
{[2.23]}\end{array}$ & $\begin{array}{l}47.994 * \\
{[1.92]}\end{array}$ & $\begin{array}{l}42.959^{* *} \\
{[2.07]}\end{array}$ & $\begin{array}{l}42.263^{* *} \\
{[2.16]}\end{array}$ & $\begin{array}{l}45.785^{*} \\
{[1.84]}\end{array}$ & $\begin{array}{l}48.348^{* *} \\
{[2.11]}\end{array}$ & $\begin{array}{l}49.854^{* *} \\
{[2.52]}\end{array}$ & $\begin{array}{l}52.025^{*} \\
{[1.84]}\end{array}$ \\
\hline $\begin{array}{l}\text { Change in gross foreign exchange } \\
\text { reserves }\end{array}$ & $\begin{array}{l}-5.512^{*} \\
{[1.68]}\end{array}$ & $\begin{array}{l}-4.825 \\
{[1.43]}\end{array}$ & $\begin{array}{l}-0.875 \\
{[0.29]}\end{array}$ & $\begin{array}{l}-5.843^{*} \\
{[1.70]}\end{array}$ & $\begin{array}{l}-4.972 \\
{[1.50]}\end{array}$ & $\begin{array}{l}-0.719 \\
{[0.23]}\end{array}$ & $\begin{array}{l}-6.812^{* *} \\
{[2.04]}\end{array}$ & $\begin{array}{l}-6.071^{*} \\
{[1.78]}\end{array}$ & $\begin{array}{l}-3.103 \\
{[0.88]}\end{array}$ & $\begin{array}{l}-4.234 \\
{[1.25]}\end{array}$ & $\begin{array}{l}-3.992 \\
{[1.23]}\end{array}$ & $\begin{array}{l}-0.389 \\
{[0.12]}\end{array}$ & $\begin{array}{l}-2.615 \\
{[0.72]}\end{array}$ & $\begin{array}{l}-2.391 \\
{[0.67]}\end{array}$ & $\begin{array}{l}1.884 \\
{[0.54]}\end{array}$ \\
\hline Foreign direct investment & & & & $\begin{array}{l}6.667^{* *} \\
{[2.05]}\end{array}$ & $\begin{array}{l}5.654 \\
{[1.53]}\end{array}$ & $\begin{array}{l}5.098 \\
{[1.52]}\end{array}$ & & & & & & & & & \\
\hline $\begin{array}{l}\text { Share of exports to anchor currency } \\
\text { country }\end{array}$ & & & & & & & $\begin{array}{l}-0.186 \\
{[0.65]}\end{array}$ & $\begin{array}{l}-0.275 \\
{[0.86]}\end{array}$ & $\begin{array}{l}-0.301 \\
{[0.87]}\end{array}$ & & & & & & \\
\hline $\begin{array}{l}\text { Share of exports to anchor currency } \\
\text { country*developed countries }\end{array}$ & & & & & & & $\begin{array}{l}0.543 * * \\
{[2.31]}\end{array}$ & $\begin{array}{l}0.594 \\
{[1.50]}\end{array}$ & $\begin{array}{l}0.822 * * \\
{[2.66]}\end{array}$ & & & & & & \\
\hline Budget balance & & & & & & & & & & $\begin{array}{l}2.682^{*} \\
{[1.73]}\end{array}$ & $\begin{array}{l}2.426 \\
{[1.22]}\end{array}$ & $\begin{array}{l}4.136^{* *} \\
{[2.28]}\end{array}$ & $\begin{array}{l}1.746 \\
{[0.83]}\end{array}$ & $\begin{array}{l}0.979 \\
{[0.42]}\end{array}$ & $\begin{array}{l}2.684 \\
{[1.19]}\end{array}$ \\
\hline Openness & & & & & & & & & & & & & $\begin{array}{l}0.400^{*} \\
{[1.86]}\end{array}$ & $\begin{array}{l}0.440^{*} \\
{[1.70]}\end{array}$ & $\begin{array}{l}0.512^{*} \\
{[1.99]}\end{array}$ \\
\hline Exit (selection) equation & & & & & & & & & & & & & & & \\
\hline $\begin{array}{l}\text { Change in gross foreign exchange } \\
\text { reserves }\end{array}$ & $\begin{array}{l}-0.085^{* *} \\
{[2.51]}\end{array}$ & $\begin{array}{l}-0.083^{* *} \\
{[1.97]}\end{array}$ & & $\begin{array}{l}-0.082^{* *} \\
{[2.44]}\end{array}$ & $\begin{array}{l}-0.083^{* *} \\
{[1.97]}\end{array}$ & & $\begin{array}{l}-0.082^{* *} \\
{[2.56]}\end{array}$ & $\begin{array}{l}-0.083^{* *} \\
{[1.97]}\end{array}$ & & $\begin{array}{l}-0.094^{* * *} \\
{[2.65]}\end{array}$ & $\begin{array}{l}-0.091^{* *} \\
{[2.05]}\end{array}$ & & $\begin{array}{l}-0.109^{* * *} \\
{[2.93]}\end{array}$ & $\begin{array}{l}-0.108^{* *} \\
{[2.30]}\end{array}$ & \\
\hline Output gap & $\begin{array}{l}0.100^{* * * *} \\
{[3.98]}\end{array}$ & $\begin{array}{l}0.106 * * * \\
{[3.95]}\end{array}$ & & $\begin{array}{l}0.101 * * * \\
{[4.01]}\end{array}$ & $\begin{array}{l}0.106^{* * * *} \\
{[3.95]}\end{array}$ & & $\begin{array}{l}0.099 * * * \\
{[4.06]}\end{array}$ & $\begin{array}{l}0.106^{* * *} \\
{[3.95]}\end{array}$ & & $\begin{array}{l}0.110^{* * * *} \\
{[3.98]}\end{array}$ & $\begin{array}{l}0.116^{* * *} \\
{[4.18]}\end{array}$ & & $\begin{array}{l}0.115^{* * * *} \\
{[4.06]}\end{array}$ & $\begin{array}{l}0.117^{* * *} \\
{[4.18]}\end{array}$ & \\
\hline Overvaluation & $\begin{array}{l}0.058 * * * \\
{[4.39]}\end{array}$ & $\begin{array}{l}0.060^{* * * *} \\
{[3.97]}\end{array}$ & & $\begin{array}{l}0.058 * * * \\
{[4.52]}\end{array}$ & $\begin{array}{l}0.060^{* * * *} \\
{[3.97]}\end{array}$ & & $\begin{array}{l}0.058^{* * *} \\
{[4.36]}\end{array}$ & $\begin{array}{l}0.060^{* * *} \\
{[3.97]}\end{array}$ & & $\begin{array}{l}0.058^{* * *} \\
{[3.96]}\end{array}$ & $\begin{array}{l}0.061^{* * *} \\
{[3.86]}\end{array}$ & & $\begin{array}{l}0.059 * * * \\
{[3.86]}\end{array}$ & $\begin{array}{l}0.061 * * * \\
{[3.83]}\end{array}$ & \\
\hline M2/GDP ratio & $\begin{array}{l}-0.021 * * * \\
{[4.64]}\end{array}$ & $\begin{array}{l}-0.017^{* * *} \\
{[3.10]}\end{array}$ & & $\begin{array}{l}-0.021^{* * * *} \\
{[4.82]}\end{array}$ & $\begin{array}{l}-0.017^{* * *} \\
{[3.10]}\end{array}$ & & $\begin{array}{l}-0.020 * * * \\
{[4.60]}\end{array}$ & $\begin{array}{l}-0.017^{* * *} \\
{[3.10]}\end{array}$ & & $\begin{array}{l}-0.022 * * * \\
{[4.28]}\end{array}$ & $\begin{array}{l}-0.019 * * * \\
{[3.22]}\end{array}$ & & $\begin{array}{l}-0.023^{* * *} \\
{[4.51]}\end{array}$ & $\begin{array}{l}-0.020^{* * * *} \\
{[3.31]}\end{array}$ & \\
\hline Incidence of exits & $\begin{array}{l}2.935^{* *} \\
{[2.23]}\end{array}$ & $\begin{array}{l}3.380^{*} \\
{[1.84]}\end{array}$ & & $\begin{array}{l}3.047 * * \\
{[2.34]}\end{array}$ & $\begin{array}{l}3.380^{*} \\
{[1.84]}\end{array}$ & & $\begin{array}{l}2.881 * * \\
{[2.19]}\end{array}$ & $\begin{array}{l}3.380^{*} \\
{[1.84]}\end{array}$ & & $\begin{array}{l}3.554 * * \\
{[2.40]}\end{array}$ & $\begin{array}{l}3.938^{* *} \\
{[2.07]}\end{array}$ & & $\begin{array}{l}3.371 * * \\
{[2.21]}\end{array}$ & $\begin{array}{l}3.657^{*} \\
{[1.88]}\end{array}$ & \\
\hline Volatility of terms of trade & $\begin{array}{l}0.020^{* *} \\
{[2.20]}\end{array}$ & $\begin{array}{l}0.024^{* *} \\
{[2.10]}\end{array}$ & & $\begin{array}{l}0.017^{*} \\
{[1.78]}\end{array}$ & $\begin{array}{l}0.024 * * \\
{[2.10]}\end{array}$ & & $\begin{array}{l}0.019^{*} \\
{[1.78]}\end{array}$ & $\begin{array}{l}0.024 * * \\
{[2.10]}\end{array}$ & & $\begin{array}{l}0.007 \\
{[0.54]}\end{array}$ & $\begin{array}{l}0.005 \\
{[0.34]}\end{array}$ & & $\begin{array}{l}0.005 \\
{[0.34]}\end{array}$ & $\begin{array}{l}0.005 \\
{[0.33]}\end{array}$ & \\
\hline GDP at current US dollars (in log) & $\begin{array}{l}0.299^{* * * *} \\
{[4.28]}\end{array}$ & $\begin{array}{l}0.302 * * * \\
{[4.05]}\end{array}$ & & $\begin{array}{l}0.302 * * * \\
{[4.34]}\end{array}$ & $\begin{array}{l}0.302^{* * * *} \\
{[4.05]}\end{array}$ & & $\begin{array}{l}0.303 * * * \\
{[4.36]}\end{array}$ & $\begin{array}{l}0.302^{* * *} \\
{[4.05]}\end{array}$ & & $\begin{array}{l}0.319^{* * * *} \\
{[4.03]}\end{array}$ & $\begin{array}{l}0.319^{* * * *} \\
{[4.11]}\end{array}$ & & $\begin{array}{l}0.320^{* * *} \\
{[3.96]}\end{array}$ & $\begin{array}{l}0.323 * * * \\
{[4.08]}\end{array}$ & \\
\hline Foreign direct investment & $\begin{array}{l}0.064 \\
{[1.35]}\end{array}$ & $\begin{array}{l}0.093 * \\
{[1.95]}\end{array}$ & & $\begin{array}{l}0.095 * * \\
{[2.04]}\end{array}$ & $\begin{array}{l}0.093 * \\
{[1.95]}\end{array}$ & & $\begin{array}{l}0.055 \\
{[1.03]}\end{array}$ & $\begin{array}{l}0.093^{*} \\
{[1.95]}\end{array}$ & & $\begin{array}{l}0.074 \\
{[1.54]}\end{array}$ & $\begin{array}{l}0.092 * \\
{[1.88]}\end{array}$ & & $\begin{array}{l}0.054 \\
{[0.96]}\end{array}$ & $\begin{array}{l}0.075 \\
{[1.32]}\end{array}$ & \\
\hline Volatility of investment & $\begin{array}{l}0.164 * * * \\
{[2.78]}\end{array}$ & $\begin{array}{l}0.165^{* * *} \\
{[2.92]}\end{array}$ & & $\begin{array}{l}0.159^{* * *} \\
{[2.73]}\end{array}$ & $\begin{array}{l}0.165^{* * *} \\
{[2.92]}\end{array}$ & & $\begin{array}{l}0.172 * * * \\
{[3.11]}\end{array}$ & $\begin{array}{l}0.165^{* * *} \\
{[2.92]}\end{array}$ & & $\begin{array}{l}0.208 * * * \\
{[3.53]}\end{array}$ & $\begin{array}{l}0.206 * * * \\
{[3.43]}\end{array}$ & & $\begin{array}{l}0.236 * * * \\
{[3.83]}\end{array}$ & $\begin{array}{l}0.217^{* * *} \\
{[3.51]}\end{array}$ & \\
\hline Capital controls & $\begin{array}{l}0.675 * * * \\
{[2.79]}\end{array}$ & $\begin{array}{l}0.681 * * \\
{[2.32]}\end{array}$ & & $\begin{array}{l}0.708 * * * \\
{[2.96]}\end{array}$ & $\begin{array}{l}0.681 * * \\
{[2.32]}\end{array}$ & & $\begin{array}{l}0.667^{* * * *} \\
{[2.76]}\end{array}$ & $\begin{array}{l}0.681^{* *} \\
{[2.32]}\end{array}$ & & $\begin{array}{l}0.620 * * * \\
{[2.62]}\end{array}$ & $\begin{array}{l}0.655^{* *} \\
{[2.20]}\end{array}$ & & $\begin{array}{l}0.707 * * * \\
{[2.73]}\end{array}$ & $\begin{array}{l}0.708^{* *} \\
{[2.28]}\end{array}$ & \\
\hline Observations & 389 & 389 & & 389 & 389 & & 389 & 389 & & 386 & 386 & & 379 & 379 & \\
\hline Uncensored observations & 46 & 46 & 48 & 46 & 46 & 47 & 46 & 46 & 48 & 43 & 43 & 44 & 42 & 42 & 43 \\
\hline Censored observations & 343 & 343 & & 343 & 343 & & 343 & 343 & & 343 & 343 & & 337 & 337 & \\
\hline Wald chi2 & 89.81 & 101.84 & & 97.79 & 105.67 & & 90.60 & 108.75 & & 109.93 & 114.70 & & 130.90 & 121.05 & \\
\hline rho & 0.76 & 0.66 & & 0.81 & 0.71 & & 0.76 & 0.62 & & 0.73 & 0.72 & & 0.72 & 0.75 & \\
\hline Wald test of indep. eqns. & 10.43 & & & 8.33 & & & 8.34 & & & 8.48 & & & 5.91 & & \\
\hline Prob $>$ chi 2 & 0.0012 & & & 0.0039 & & & 0.0039 & & & 0.0036 & & & 0.0151 & & \\
\hline Mill's ratio & & $\begin{array}{l}35.677 * * \\
{[1.99]}\end{array}$ & & & $\begin{array}{l}38.660^{* *} \\
{[2.18]}\end{array}$ & & & $\begin{array}{l}31.900^{*} \\
{[1.78]}\end{array}$ & & & $\begin{array}{l}36.430^{* *} \\
{[2.15]}\end{array}$ & & & $\begin{array}{l}37.735^{* *} \\
{[2.31]}\end{array}$ & \\
\hline R squared & & & 0.61 & & & 0.61 & & & 0.62 & & & 0.69 & & & 0.71 \\
\hline
\end{tabular}

Robust z statistics in brackets; * significant at 10\%, ${ }^{* *}$ significant at $5 \%, * * *$ significant at $1 \%$. Constant not reported. 
Table 5. The Output Gap Model

\begin{tabular}{|c|c|c|c|c|c|c|c|c|c|c|c|c|c|c|c|}
\hline \multirow[b]{2}{*}{ Change in output gap } & \multicolumn{3}{|c|}{ Benchmark } & \multicolumn{3}{|c|}{1} & \multicolumn{3}{|c|}{2} & \multicolumn{3}{|c|}{3} & \multicolumn{3}{|c|}{4} \\
\hline & ML & Two-steps & OLS & ML & Two-steps & OLS & ML & Two-steps & OLS & ML & Two-steps & OLS & ML & Two-steps & OLS \\
\hline Duration & $\begin{array}{l}-0.013^{* *} \\
{[2.02]}\end{array}$ & $\begin{array}{l}-0.010^{* *} \\
{[1.98]}\end{array}$ & $\begin{array}{l}-0.016^{* *} \\
{[2.17]}\end{array}$ & $\begin{array}{l}-0.012^{* *} \\
{[2.23]}\end{array}$ & $\begin{array}{l}-0.010^{* *} \\
{[2.28]}\end{array}$ & $\begin{array}{l}-0.018^{* *} \\
{[2.64]}\end{array}$ & $\begin{array}{l}-0.017 * * \\
{[2.52]}\end{array}$ & $\begin{array}{l}-0.011^{* *} \\
{[2.13]}\end{array}$ & $\begin{array}{l}-0.020^{* *} \\
{[2.69]}\end{array}$ & $\begin{array}{l}-0.015^{* * *} \\
{[3.13]}\end{array}$ & $\begin{array}{l}-0.013^{* * *} \\
{[2.66]}\end{array}$ & $\begin{array}{l}-0.009 \\
{[1.54]}\end{array}$ & $\begin{array}{l}-0.016^{* *} \\
{[2.48]}\end{array}$ & $\begin{array}{l}-0.013^{* *} \\
{[2.48]}\end{array}$ & $\begin{array}{l}-0.016^{* *} \\
{[2.17]}\end{array}$ \\
\hline Output gap (lagged) & $\begin{array}{l}-0.873 * * * \\
{[10.32]}\end{array}$ & $\begin{array}{l}-0.881 * * * \\
{[9.32]}\end{array}$ & $\begin{array}{l}-0.915^{* * *} \\
{[7.69]}\end{array}$ & $\begin{array}{l}-0.904 * * * \\
{[12.38]}\end{array}$ & $\begin{array}{l}-0.929^{* * *} \\
{[11.27]}\end{array}$ & $\begin{array}{l}-0.904 * * * \\
{[8.02]}\end{array}$ & $\begin{array}{l}-0.866 * * * \\
{[10.06]}\end{array}$ & $\begin{array}{l}-0.887^{* * * *} \\
{[9.74]}\end{array}$ & $\begin{array}{l}-0.918^{* * *} \\
{[7.59]}\end{array}$ & $\begin{array}{l}-0.859 * * * \\
{[13.28]}\end{array}$ & $\begin{array}{l}-0.853^{* * * *} \\
{[9.00]}\end{array}$ & $\begin{array}{l}-1.025 * * * \\
{[10.02]}\end{array}$ & $\begin{array}{l}-0.863 * * * \\
{[8.84]}\end{array}$ & $\begin{array}{l}-0.884^{* * *} \\
{[9.53]}\end{array}$ & $\begin{array}{l}-0.915^{* * *} \\
{[7.69]}\end{array}$ \\
\hline Credit to the public sector & $\begin{array}{l}0.098^{* * *} \\
{[3.01]}\end{array}$ & $\begin{array}{l}0.096^{* * *} \\
{[3.06]}\end{array}$ & $\begin{array}{l}0.099 * * \\
{[2.06]}\end{array}$ & $\begin{array}{l}0.086^{* * *} \\
{[2.77]}\end{array}$ & $\begin{array}{l}0.083^{* * *} \\
{[2.97]}\end{array}$ & $\begin{array}{l}0.090^{*} \\
{[1.72]}\end{array}$ & $\begin{array}{l}0.119^{* * *} \\
{[4.28]}\end{array}$ & $\begin{array}{l}0.107^{* * * *} \\
{[3.57]}\end{array}$ & $\begin{array}{l}0.123 * * \\
{[2.44]}\end{array}$ & $\begin{array}{l}0.081^{* * *} \\
{[2.60]}\end{array}$ & $\begin{array}{l}0.072^{* *} \\
{[2.42]}\end{array}$ & $\begin{array}{l}0.076^{*} \\
{[1.87]}\end{array}$ & $\begin{array}{l}0.074^{* *} \\
{[2.39]}\end{array}$ & $\begin{array}{l}0.074 * * \\
{[2.24]}\end{array}$ & $\begin{array}{l}0.099^{* *} \\
{[2.06]}\end{array}$ \\
\hline $\begin{array}{l}\text { Ratio of liquid bank reserves to bank } \\
\text { assets }\end{array}$ & $\begin{array}{l}0.152^{* * *} \\
{[4.55]}\end{array}$ & $\begin{array}{l}0.153^{* * *} \\
{[4.68]}\end{array}$ & $\begin{array}{l}0.02 \\
{[0.34]}\end{array}$ & $\begin{array}{l}0.149^{* * *} \\
{[4.74]}\end{array}$ & $\begin{array}{l}0.148^{* * *} \\
{[5.29]}\end{array}$ & $\begin{array}{l}0.008 \\
{[0.13]}\end{array}$ & $\begin{array}{l}0.165^{* * *} \\
{[4.92]}\end{array}$ & $\begin{array}{l}0.161^{* * *} \\
{[5.12]}\end{array}$ & $\begin{array}{l}0.024 \\
{[0.40]}\end{array}$ & $\begin{array}{l}0.146 * * * \\
{[4.36]}\end{array}$ & $\begin{array}{l}0.146 * * * \\
{[4.63]}\end{array}$ & $\begin{array}{l}0.113 * * * \\
{[2.91]}\end{array}$ & $\begin{array}{l}0.160^{* * *} \\
{[4.33]}\end{array}$ & $\begin{array}{l}0.156 * * * \\
{[4.45]}\end{array}$ & $\begin{array}{l}0.02 \\
{[0.34]}\end{array}$ \\
\hline Capital controls & $\begin{array}{l}3.337^{* * *} \\
{[3.07]}\end{array}$ & $\begin{array}{l}3.369^{* * *} \\
{[3.19]}\end{array}$ & $\begin{array}{l}3.395 * * \\
{[2.25]}\end{array}$ & $\begin{array}{l}2.350^{* * *} \\
{[2.37]}\end{array}$ & $\begin{array}{l}2.419^{* *} \\
{[2.53]}\end{array}$ & $\begin{array}{l}2.498^{*} \\
{[1.79]}\end{array}$ & $\begin{array}{l}2.825 * * * \\
{[2.85]}\end{array}$ & $\begin{array}{l}2.995 * * * \\
{[2.99]}\end{array}$ & $\begin{array}{l}2.876^{*} \\
{[1.92]}\end{array}$ & $\begin{array}{l}3.336^{* * * *} \\
{[2.74]}\end{array}$ & $\begin{array}{l}3.822 * * * \\
{[3.34]}\end{array}$ & $\begin{array}{l}3.693^{* *} \\
{[2.36]}\end{array}$ & $\begin{array}{l}3.447^{* * *} \\
{[3.01]}\end{array}$ & $\begin{array}{l}3.477 * * * \\
{[3.30]}\end{array}$ & $\begin{array}{l}3.395^{* *} \\
{[2.25]}\end{array}$ \\
\hline Foreign direct investment & $\begin{array}{l}0.607 * * * \\
{[2.61]}\end{array}$ & $\begin{array}{l}0.618^{* *} \\
{[2.53]}\end{array}$ & $\begin{array}{l}0.484 \\
{[1.67]}\end{array}$ & $\begin{array}{l}0.491 * * \\
{[2.40]}\end{array}$ & $\begin{array}{l}0.474 * * \\
{[2.14]}\end{array}$ & $\begin{array}{l}0.403 \\
{[1.58]}\end{array}$ & $\begin{array}{l}0.582 * * * \\
{[3.13]}\end{array}$ & $\begin{array}{l}0.594 * * \\
{[2.45]}\end{array}$ & $\begin{array}{l}0.408 \\
{[1.68]}\end{array}$ & $\begin{array}{l}0.608^{* * * *} \\
{[2.66]}\end{array}$ & $\begin{array}{l}0.588 * * \\
{[2.56]}\end{array}$ & $\begin{array}{l}0.471^{*} \\
{[1.74]}\end{array}$ & $\begin{array}{l}0.605^{* * *} \\
{[2.58]}\end{array}$ & $\begin{array}{l}0.625^{* *} \\
{[2.57]}\end{array}$ & $\begin{array}{l}0.484 \\
{[1.67]}\end{array}$ \\
\hline Openness & $\begin{array}{l}0.018^{* *} \\
{[2.37]}\end{array}$ & $\begin{array}{l}0.016 \\
{[1.59]}\end{array}$ & $\begin{array}{l}0.024 * * * \\
{[2.80]}\end{array}$ & $\begin{array}{l}0.013^{*} \\
{[1.84]}\end{array}$ & $\begin{array}{l}0.012 \\
{[1.36]}\end{array}$ & $\begin{array}{l}0.019^{* *} \\
{[2.13]}\end{array}$ & $\begin{array}{l}0.022^{* * * *} \\
{[2.89]}\end{array}$ & $\begin{array}{l}0.016 \\
{[1.56]}\end{array}$ & $\begin{array}{l}0.031 \text { *** } \\
{[3.40]}\end{array}$ & $\begin{array}{l}0.014^{*} \\
{[1.81]}\end{array}$ & $\begin{array}{l}0.014 \\
{[1.53]}\end{array}$ & $\begin{array}{l}0.019^{*} \\
{[2.02]}\end{array}$ & $\begin{array}{l}0.021^{* * *} \\
{[2.68]}\end{array}$ & $\begin{array}{l}0.019^{* *} \\
{[1.99]}\end{array}$ & $\begin{array}{l}0.024 * * * \\
{[2.80]}\end{array}$ \\
\hline Overvaluation & & & & $\begin{array}{l}-0.064 \\
{[1.62]}\end{array}$ & $\begin{array}{l}-0.074^{*} \\
{[1.92]}\end{array}$ & $\begin{array}{l}-0.046 \\
{[1.13]}\end{array}$ & & & & & & & & & \\
\hline Volatility of investment & & & & & & & $\begin{array}{l}-0.251^{* *} \\
{[2.12]}\end{array}$ & $\begin{array}{l}-0.174 \\
{[1.12]}\end{array}$ & $\begin{array}{l}-0.188 \\
{[0.92]}\end{array}$ & & & & & & \\
\hline $\begin{array}{l}\text { External public debt*developed } \\
\text { country }\end{array}$ & & & & & & & $\begin{array}{l}0.104 * * * \\
{[5.93]}\end{array}$ & $\begin{array}{l}0.086^{* * *} \\
{[2.92]}\end{array}$ & $\begin{array}{l}0.127^{* * *} \\
{[6.68]}\end{array}$ & & & & & & \\
\hline Change in real money supply (M2) & & & & $\begin{array}{l}0.077^{* *} \\
{[2.54]}\end{array}$ & $\begin{array}{l}0.071^{* *} \\
{[2.56]}\end{array}$ & $\begin{array}{l}0.076^{*} \\
{[1.96]}\end{array}$ & & & & $\begin{array}{l}0.081^{* * * *} \\
{[2.86]}\end{array}$ & $\begin{array}{l}0.072 * * * \\
{[2.65]}\end{array}$ & $\begin{array}{l}0.065^{*} \\
{[1.86]}\end{array}$ & & & \\
\hline Net oil exporter & & & & & & & & & & $\begin{array}{l}1.201 * * \\
{[2.03]}\end{array}$ & $\begin{array}{l}1.585^{*} \\
{[1.89]}\end{array}$ & $\begin{array}{l}0.837 \\
{[0.81]}\end{array}$ & & & \\
\hline \multicolumn{16}{|l|}{ Exit (selection) equation } \\
\hline $\begin{array}{l}\text { Change in gross foreign exchange } \\
\text { reserves }\end{array}$ & $\begin{array}{l}-0.081^{* * *} \\
{[2.75]}\end{array}$ & $\begin{array}{l}-0.083^{* *} \\
{[1.98]}\end{array}$ & & $\begin{array}{l}-0.084^{* * *} \\
{[2.71]}\end{array}$ & $\begin{array}{l}-0.083^{* *} \\
{[1.98]}\end{array}$ & & $\begin{array}{l}-0.092^{* * *} \\
{[2.81]}\end{array}$ & $\begin{array}{l}-0.105^{* *} \\
{[2.41]}\end{array}$ & & $\begin{array}{l}-0.083^{* * *} \\
{[3.18]}\end{array}$ & $\begin{array}{l}-0.083^{* *} \\
{[1.98]}\end{array}$ & & $\begin{array}{l}-0.088^{* * *} \\
{[3.02]}\end{array}$ & $\begin{array}{l}-0.085^{*} \\
{[1.88]}\end{array}$ & \\
\hline Output gap & $\begin{array}{l}0.093 * * * \\
{[3.88]}\end{array}$ & $\begin{array}{l}0.107 * * * \\
{[3.99]}\end{array}$ & & $\begin{array}{l}0.101 * * * \\
{[4.10]}\end{array}$ & $\begin{array}{l}0.107 * * * \\
{[3.99]}\end{array}$ & & $\begin{array}{l}0.092^{* * * *} \\
{[3.58]}\end{array}$ & $\begin{array}{l}0.099 * * * \\
{[3.65]}\end{array}$ & & $\begin{array}{l}0.095^{* * *} \\
{[4.47]}\end{array}$ & $\begin{array}{l}0.107 * * * \\
{[3.99]}\end{array}$ & & $\begin{array}{l}0.086^{* * *} \\
{[3.14]}\end{array}$ & $\begin{array}{l}0.108 * * * \\
{[3.79]}\end{array}$ & \\
\hline Overvaluation & $\begin{array}{l}0.065^{* * *} \\
{[5.04]}\end{array}$ & $\begin{array}{l}0.060^{* * *} \\
{[3.97]}\end{array}$ & & $\begin{array}{l}0.059^{* * * *} \\
{[4.09]}\end{array}$ & $\begin{array}{l}0.060^{* * *} \\
{[3.97]}\end{array}$ & & $\begin{array}{l}0.069^{* * *} \\
{[5.88]}\end{array}$ & $\begin{array}{l}0.062 * * * \\
{[4.21]}\end{array}$ & & $\begin{array}{l}0.063 * * * \\
{[4.98]}\end{array}$ & $\begin{array}{l}0.060^{* * *} \\
{[3.97]}\end{array}$ & & $\begin{array}{l}0.070^{* * *} \\
{[4.92]}\end{array}$ & $\begin{array}{l}0.064 * * * \\
{[3.94]}\end{array}$ & \\
\hline M2/GDP ratio & $\begin{array}{l}-0.017^{* * *} \\
{[4.16]}\end{array}$ & $\begin{array}{l}-0.017 * * * \\
{[3.09]}\end{array}$ & & $\begin{array}{l}-0.018^{* * *} \\
{[4.25]}\end{array}$ & $\begin{array}{l}-0.017^{* * *} \\
{[3.09]}\end{array}$ & & $\begin{array}{l}-0.019^{* * *} \\
{[4.35]}\end{array}$ & $\begin{array}{l}-0.017^{* * *} \\
{[3.16]}\end{array}$ & & $\begin{array}{l}-0.018^{* * *} \\
{[4.19]}\end{array}$ & $\begin{array}{l}-0.017^{* * * *} \\
{[3.09]}\end{array}$ & & $\begin{array}{l}-0.017^{* * *} \\
{[3.51]}\end{array}$ & $\begin{array}{l}-0.019^{* * * *} \\
{[3.08]}\end{array}$ & \\
\hline Incidence of exits & $\begin{array}{l}2.836^{* *} \\
{[2.10]}\end{array}$ & $\begin{array}{l}3.423 * \\
{[1.87]}\end{array}$ & & $\begin{array}{l}2.987^{* *} \\
{[2.02]}\end{array}$ & $\begin{array}{l}3.423 * \\
{[1.87]}\end{array}$ & & $\begin{array}{l}1.141 \\
{[0.90]}\end{array}$ & $\begin{array}{l}2.665 \\
{[1.42]}\end{array}$ & & $\begin{array}{l}2.761 * * \\
{[2.13]}\end{array}$ & $\begin{array}{l}3.423 * \\
{[1.87]}\end{array}$ & & $\begin{array}{l}2.955^{*} \\
{[1.93]}\end{array}$ & $\begin{array}{l}3.980^{* *} \\
{[2.05]}\end{array}$ & \\
\hline Volatility of terms of trade & $\begin{array}{l}0.018^{*} \\
{[1.85]}\end{array}$ & $\begin{array}{l}0.024^{* *} \\
{[2.10]}\end{array}$ & & $\begin{array}{l}0.017^{*} \\
{[1.74]}\end{array}$ & $\begin{array}{l}0.024^{* *} \\
{[2.10]}\end{array}$ & & $\begin{array}{l}0.014 \\
{[1.35]}\end{array}$ & $\begin{array}{l}0.031^{* * * *} \\
{[2.75]}\end{array}$ & & $\begin{array}{l}0.015 \\
{[1.59]}\end{array}$ & $\begin{array}{l}0.024 * * \\
{[2.10]}\end{array}$ & & $\begin{array}{l}0.024 \\
{[1.47]}\end{array}$ & $\begin{array}{l}0.015 \\
{[0.84]}\end{array}$ & \\
\hline GDP at current US dollars (in log) & $\begin{array}{l}0.258^{* * *} \\
{[3.22]}\end{array}$ & $\begin{array}{l}0.303^{* * * *} \\
{[4.08]}\end{array}$ & & $\begin{array}{l}0.276^{* * *} \\
{[3.18]}\end{array}$ & $\begin{array}{l}0.303 * * * \\
{[4.08]}\end{array}$ & & $\begin{array}{l}0.183^{* * * *} \\
{[2.65]}\end{array}$ & $\begin{array}{l}0.239^{* * *} \\
{[3.35]}\end{array}$ & & $\begin{array}{l}0.260^{* * * *} \\
{[3.35]}\end{array}$ & $\begin{array}{l}0.303 * * * \\
{[4.08]}\end{array}$ & & $\begin{array}{l}0.265 * * * \\
{[2.62]}\end{array}$ & $\begin{array}{l}0.327 * * * \\
{[4.03]}\end{array}$ & \\
\hline Foreign direct investment & $\begin{array}{l}0.094^{* *} \\
{[2.26]}\end{array}$ & $\begin{array}{l}0.093^{*} \\
{[1.95]}\end{array}$ & & $\begin{array}{l}0.092^{* *} \\
{[2.20]}\end{array}$ & $\begin{array}{l}0.093^{*} \\
{[1.95]}\end{array}$ & & $\begin{array}{l}0.109^{* * *} \\
{[2.68]}\end{array}$ & $\begin{array}{l}0.115^{* *} \\
{[2.48]}\end{array}$ & & $\begin{array}{l}0.091^{* *} \\
{[2.22]}\end{array}$ & $\begin{array}{l}0.093^{*} \\
{[1.95]}\end{array}$ & & $\begin{array}{l}0.109^{* *} \\
{[2.35]}\end{array}$ & $\begin{array}{l}0.098^{*} \\
{[1.79]}\end{array}$ & \\
\hline Volatility of investment & $\begin{array}{l}0.144 * * * \\
{[2.94]}\end{array}$ & $\begin{array}{l}0.165^{* * * *} \\
{[2.92]}\end{array}$ & & $\begin{array}{l}0.164^{* * *} \\
{[3.09]}\end{array}$ & $\begin{array}{l}0.165^{* * * *} \\
{[2.92]}\end{array}$ & & & & & $\begin{array}{l}0.154^{* * * *} \\
{[3.55]}\end{array}$ & $\begin{array}{l}0.165^{* * *} \\
{[2.92]}\end{array}$ & & $\begin{array}{l}0.166^{* * * *} \\
{[2.98]}\end{array}$ & $\begin{array}{l}0.214 * * * \\
{[3.41]}\end{array}$ & \\
\hline Capital controls & $\begin{array}{l}0.693 * * * \\
{[2.92]}\end{array}$ & $\begin{array}{l}0.681^{* *} \\
{[2.32]}\end{array}$ & & $\begin{array}{l}0.707^{* * * *} \\
{[3.00]}\end{array}$ & $\begin{array}{l}0.681 * * \\
{[2.32]}\end{array}$ & & $\begin{array}{l}0.545^{\text {*** }} \\
{[2.38]}\end{array}$ & $\begin{array}{l}0.560^{*} \\
{[1.95]}\end{array}$ & & $\begin{array}{l}0.7311^{* * *} \\
{[3.22]}\end{array}$ & $\begin{array}{l}0.681 * * \\
{[2.32]}\end{array}$ & & $\begin{array}{l}0.768^{* * * *} \\
{[2.94]}\end{array}$ & $\begin{array}{l}0.775 * * \\
{[2.43]}\end{array}$ & \\
\hline Change in budget balance & & & & & & & & & & & & & $\begin{array}{l}-0.108^{* * *} \\
{[2.69]}\end{array}$ & $\begin{array}{l}-0.101^{* *} \\
{[2.03]}\end{array}$ & \\
\hline Observations & 393 & 393 & 48 & 393 & 393 & 48 & 391 & 391 & 45 & 393 & 393 & 47 & 377 & 377 & \\
\hline Uncensored observations & 46 & 46 & 48 & 46 & 46 & 48 & 43 & 43 & 45 & 46 & 46 & 47 & 43 & 43 & \\
\hline Censored observations & 347 & 347 & & 347 & 347 & & 348 & 348 & & 347 & 347 & & 334 & 334 & \\
\hline Wald chi2 & 278.66 & 209.86 & & 505.97 & 308.04 & & 274.29 & 226.07 & & 509.83 & 230.67 & & 221.87 & 208.16 & \\
\hline rho & 0.79 & 0.81 & & 0.74 & 0.63 & & 0.88 & 0.82 & & 0.89 & 0.92 & & 0.82 & 0.79 & \\
\hline Wald test of indep. eqns. & 13 & & & 5.31 & & & 19.5 & & & 14.59 & & & 7.78 & & \\
\hline Prob $>$ chi 2 & 0.000 & & & 0.021 & & & 0.000 & & & 0.000 & & & 0.005 & & \\
\hline Mill's ratio & & $\begin{array}{l}2.433^{* * *} \\
{[3.51]}\end{array}$ & & & $\begin{array}{l}1.513^{*} \\
{[1.95]}\end{array}$ & & & $\begin{array}{l}2.327 * * * \\
{[3.26]}\end{array}$ & & & $\begin{array}{l}2.799 * * * \\
{[4.04]}\end{array}$ & & & $\begin{array}{l}2.3211^{* * *} \\
{[3.49]}\end{array}$ & \\
\hline R-squared & & & 0.78 & & & 0.80 & & & 0.81 & & & 0.86 & & & 0.78 \\
\hline
\end{tabular}

Robust z statistics in brackets; * significant at $10 \%,{ }^{* *}$ significant at $5 \%,{ }^{* *}$ significant at $1 \%$. Constant not reported. 


\section{Table 6. Alternative Definitions of Exits: Exchange Rate Model}

\begin{tabular}{|c|c|c|c|c|c|}
\hline & $\begin{array}{c}\text { Benchmark } \\
\text { sample }\end{array}$ & Alternative 1 & Alternative 2 & Alternative 3 & Alternative 4 \\
\hline Change in exchange rate & ML & ML & ML & ML & ML \\
\hline Inflation & $\begin{array}{l}-1.771 * * * \\
{[3.18]}\end{array}$ & $\begin{array}{l}-2.572 \\
{[1.29]}\end{array}$ & $\begin{array}{l}-1.691 * * \\
{[2.02]}\end{array}$ & $\begin{array}{l}-0.916 \\
{[1.19]}\end{array}$ & $\begin{array}{l}-0.394 \\
{[1.01]}\end{array}$ \\
\hline Overvaluation & $\begin{array}{l}-2.817^{* * * *} \\
{[3.43]}\end{array}$ & $\begin{array}{l}-2.660^{* * *} \\
{[2.58]}\end{array}$ & $\begin{array}{l}-1.734 \\
{[1.51]}\end{array}$ & $\begin{array}{l}-1.742 * * \\
{[2.07]}\end{array}$ & $\begin{array}{l}-2.318^{* * *} \\
{[3.82]}\end{array}$ \\
\hline Output gap (lagged) & $\begin{array}{l}5.070 * * \\
{[2.41]}\end{array}$ & $\begin{array}{l}8.400 \\
{[1.32]}\end{array}$ & $\begin{array}{l}1.571 \\
{[0.71]}\end{array}$ & $\begin{array}{l}3.690 * \\
{[1.87]}\end{array}$ & $\begin{array}{l}4.665 \\
{[1.57]}\end{array}$ \\
\hline Change in money supply (M2) & $\begin{array}{l}-1.147^{* * * *} \\
{[3.12]}\end{array}$ & $\begin{array}{l}-2.052^{* *} \\
{[2.31]}\end{array}$ & $\begin{array}{l}-1.186^{*} \\
{[1.78]}\end{array}$ & $\begin{array}{l}-1.695^{* * *} \\
{[3.32]}\end{array}$ & $\begin{array}{l}-1.386^{*} \\
{[1.76]}\end{array}$ \\
\hline Change in US interest rate & $\begin{array}{l}-17.873^{* *} \\
{[2.11]}\end{array}$ & $\begin{array}{l}-8.759 \\
{[0.84]}\end{array}$ & $\begin{array}{l}-12.953 \\
{[1.16]}\end{array}$ & $\begin{array}{l}-12.444 * \\
{[1.65]}\end{array}$ & $\begin{array}{l}122.590 * \\
{[1.94]}\end{array}$ \\
\hline Capital controls & $\begin{array}{l}43.192 * * \\
{[2.02]}\end{array}$ & $\begin{array}{l}47.591^{* *} \\
{[2.17]}\end{array}$ & $\begin{array}{l}63.198^{* *} \\
{[2.31]}\end{array}$ & $\begin{array}{l}47.014^{*} \\
{[1.95]}\end{array}$ & $\begin{array}{l}90.358^{* * *} \\
{[2.53]}\end{array}$ \\
\hline $\begin{array}{l}\text { Change in gross foreign exchange } \\
\text { reserves }\end{array}$ & $\begin{array}{l}-5.512^{*} \\
{[1.68]}\end{array}$ & $\begin{array}{l}-6.080 \\
{[0.97]}\end{array}$ & $\begin{array}{l}-1.013 \\
{[0.38]}\end{array}$ & $\begin{array}{l}-3.756 \\
{[1.11]}\end{array}$ & $\begin{array}{l}2.350 \\
{[0.69]}\end{array}$ \\
\hline \multicolumn{6}{|l|}{ Exit (selection) equation } \\
\hline $\begin{array}{l}\text { Change in gross foreign exchange } \\
\text { reserves }\end{array}$ & $\begin{array}{l}-0.085^{* *} \\
{[2.51]}\end{array}$ & $\begin{array}{l}-0.073^{*} \\
{[1.79]}\end{array}$ & $\begin{array}{l}-0.032 \\
{[0.91]}\end{array}$ & $\begin{array}{l}-0.050 * \\
{[1.68]}\end{array}$ & $\begin{array}{l}-0.126^{* * *} \\
{[3.21]}\end{array}$ \\
\hline Output gap & $\begin{array}{l}0.100^{* * * *} \\
{[3.98]}\end{array}$ & $\begin{array}{l}0.131^{* * * *} \\
{[3.65]}\end{array}$ & $\begin{array}{l}0.063^{* * * *} \\
{[3.00]}\end{array}$ & $\begin{array}{l}0.087 * * * \\
{[3.80]}\end{array}$ & $\begin{array}{l}0.036 \\
{[1.41]}\end{array}$ \\
\hline Overvaluation & $\begin{array}{l}0.058 * * * \\
{[4.39]}\end{array}$ & $\begin{array}{l}0.020 \\
{[0.95]}\end{array}$ & $\begin{array}{l}0.070^{* * * *} \\
{[4.82]}\end{array}$ & $\begin{array}{l}0.065^{* * *} \\
{[5.34]}\end{array}$ & $\begin{array}{l}0.002 \\
{[1.15]}\end{array}$ \\
\hline $\mathrm{M} 2 / \mathrm{GDP}$ ratio & $\begin{array}{l}-0.021 * * * \\
{[4.64]}\end{array}$ & $\begin{array}{l}-0.014 * * * \\
{[3.27]}\end{array}$ & $\begin{array}{l}-0.005 \\
{[1.15]}\end{array}$ & $\begin{array}{l}-0.020 * * * \\
{[5.10]}\end{array}$ & $\begin{array}{l}-0.010^{* * *} \\
{[2.74]}\end{array}$ \\
\hline Incidence of exits & $\begin{array}{l}2.935^{* *} \\
{[2.23]}\end{array}$ & $\begin{array}{l}4.377 * * * \\
{[2.72]}\end{array}$ & $\begin{array}{l}1.969 \\
{[1.30]}\end{array}$ & $\begin{array}{l}2.456^{*} \\
{[1.96]}\end{array}$ & $\begin{array}{l}5.985 * * * \\
{[3.62]}\end{array}$ \\
\hline Volatility of terms of trade & $\begin{array}{l}0.020 * * \\
{[2.20]}\end{array}$ & $\begin{array}{l}0.021 \\
{[1.22]}\end{array}$ & $\begin{array}{l}0.020 * \\
{[1.68]}\end{array}$ & $\begin{array}{l}0.019 * * \\
{[2.40]}\end{array}$ & $\begin{array}{l}0.042 * * * \\
{[2.63]}\end{array}$ \\
\hline GDP at current US dollars (in log) & $\begin{array}{l}0.299 * * * \\
{[4.28]}\end{array}$ & $\begin{array}{l}0.259 \\
{[1.16]}\end{array}$ & $\begin{array}{l}0.082 \\
{[1.37]}\end{array}$ & $\begin{array}{l}0.282 * * * \\
{[4.41]}\end{array}$ & $\begin{array}{l}0.191 * * * \\
{[3.73]}\end{array}$ \\
\hline Foreign direct investment & $\begin{array}{l}0.064 \\
{[1.35]}\end{array}$ & $\begin{array}{l}0.027 \\
{[0.25]}\end{array}$ & $\begin{array}{l}0.025 \\
{[0.63]}\end{array}$ & $\begin{array}{l}0.042 \\
{[0.94]}\end{array}$ & $\begin{array}{l}0.015 \\
{[0.54]}\end{array}$ \\
\hline Volatility of investment & $\begin{array}{l}0.164^{* * * *} \\
{[2.78]}\end{array}$ & $\begin{array}{l}0.222^{* * * *} \\
{[2.61]}\end{array}$ & $\begin{array}{l}0.082 \\
{[1.44]}\end{array}$ & $\begin{array}{l}0.135^{* *} \\
{[2.52]}\end{array}$ & $\begin{array}{l}-0.051 \\
{[0.84]}\end{array}$ \\
\hline Capital controls & $\begin{array}{l}0.675^{* * * *} \\
{[2.79]}\end{array}$ & $\begin{array}{l}0.600 \\
{[1.41]}\end{array}$ & $\begin{array}{l}0.828^{* * *} \\
{[3.86]}\end{array}$ & $\begin{array}{l}0.753^{* * * *} \\
{[3.18]}\end{array}$ & $\begin{array}{l}0.650 * * \\
{[2.53]}\end{array}$ \\
\hline Observations & 389 & 306 & 348 & 420 & 228 \\
\hline Uncensored observations & 46 & 26 & 48 & 53 & 44 \\
\hline Censored observations & 343 & 280 & 300 & 367 & 184 \\
\hline Log pseudo-likelihood & -328.01 & -188.07 & -361.28 & -380.59 & -325.08 \\
\hline Wald chi2 & 89.81 & 22.04 & 63.68 & 47.40 & 116.43 \\
\hline rho & 0.76 & 0.81 & 0.65 & 0.81 & 0.72 \\
\hline Wald test of indep. eqns. & 10.43 & 0.49 & 4.09 & 12.89 & 4.28 \\
\hline Prob $>$ chi 2 & 0.0012 & 0.4859 & 0.0432 & 0.0003 & 0.0386 \\
\hline
\end{tabular}

Robust $\mathrm{z}$ statistics in brackets; ${ }^{*}$ significant at $10 \%,{ }^{* *}$ significant at $5 \%,{ }^{* * *}$ significant at $1 \%$. Constant not reported. 
Table 7. Alternative Definitions of Exits: Output Gap Model

\begin{tabular}{|c|c|c|c|c|c|}
\hline & $\begin{array}{c}\text { Benchmark } \\
\text { sample }\end{array}$ & Alternative 1 & Alternative 2 & Alternative 3 & Alternative 4 \\
\hline Change in output gap & ML & Two-steps & ML & ML & ML \\
\hline Duration & $\begin{array}{l}-0.013 * * \\
{[2.02]}\end{array}$ & $\begin{array}{l}-0.003 \\
{[0.30]}\end{array}$ & $\begin{array}{l}-0.009 * * \\
{[2.06]}\end{array}$ & $\begin{array}{l}-0.012 * * \\
{[2.07]}\end{array}$ & $\begin{array}{l}-0.029 \\
{[1.26]}\end{array}$ \\
\hline Output gap (lagged) & $\begin{array}{l}-0.873 * * * \\
{[10.32]}\end{array}$ & $\begin{array}{l}-0.699 * * * \\
{[3.75]}\end{array}$ & $\begin{array}{l}-1.119^{* * *} \\
{[13.34]}\end{array}$ & $\begin{array}{l}-0.886^{* * * *} \\
{[11.83]}\end{array}$ & $\begin{array}{l}-0.745^{* * *} \\
{[12.01]}\end{array}$ \\
\hline Credit to the public sector & $\begin{array}{l}0.098^{* * * *} \\
{[3.01]}\end{array}$ & $\begin{array}{l}0.058 \\
{[1.33]}\end{array}$ & $\begin{array}{l}-0.004 \\
{[0.12]}\end{array}$ & $\begin{array}{l}0.092 * * * \\
{[3.05]}\end{array}$ & $\begin{array}{l}-0.004 \\
{[0.10]}\end{array}$ \\
\hline $\begin{array}{l}\text { Ratio of liquid bank reserves to } \\
\text { bank assets }\end{array}$ & $\begin{array}{l}0.152^{* * * *} \\
{[4.55]}\end{array}$ & $\begin{array}{l}0.121^{* *} \\
{[2.28]}\end{array}$ & $\begin{array}{l}0.116^{* * *} \\
{[4.22]}\end{array}$ & $\begin{array}{l}0.134^{* * *} \\
{[5.00]}\end{array}$ & $\begin{array}{l}0.08 \\
{[1.48]}\end{array}$ \\
\hline Capital controls & $\begin{array}{l}3.337 * * * \\
{[3.07]}\end{array}$ & $\begin{array}{l}4.415^{* * *} \\
{[2.59]}\end{array}$ & $\begin{array}{l}2.175^{* *} \\
{[2.04]}\end{array}$ & $\begin{array}{l}2.508 * * \\
{[2.02]}\end{array}$ & $\begin{array}{l}6.731 * * \\
{[2.42]}\end{array}$ \\
\hline Foreign direct investment & $\begin{array}{l}0.607 * * * \\
{[2.61]}\end{array}$ & $\begin{array}{l}0.257 \\
{[0.72]}\end{array}$ & $\begin{array}{l}0.686 * * \\
{[2.14]}\end{array}$ & $\begin{array}{l}0.619 * * * \\
{[2.73]}\end{array}$ & $\begin{array}{l}0.806^{* *} \\
{[2.31]}\end{array}$ \\
\hline Openness & $\begin{array}{l}0.018 * * \\
{[2.37]}\end{array}$ & $\begin{array}{l}0.014 \\
{[1.00]}\end{array}$ & $\begin{array}{l}-0.003 \\
{[0.23]}\end{array}$ & $\begin{array}{l}0.012 \\
{[1.39]}\end{array}$ & $\begin{array}{l}-0.011 \\
{[0.89]}\end{array}$ \\
\hline \multicolumn{6}{|l|}{ Exit (selection) equation } \\
\hline $\begin{array}{l}\text { Change in gross foreign exchange } \\
\text { reserves }\end{array}$ & $\begin{array}{l}-0.081 * * * \\
{[2.75]}\end{array}$ & $\begin{array}{l}-0.063 \\
{[1.28]}\end{array}$ & $\begin{array}{l}-0.031 \\
{[0.88]}\end{array}$ & $\begin{array}{l}-0.054^{* *} \\
{[2.03]}\end{array}$ & $\begin{array}{l}-0.084 * * * \\
{[2.65]}\end{array}$ \\
\hline Output gap & $\begin{array}{l}0.093 * * * \\
{[3.88]}\end{array}$ & $\begin{array}{l}0.118^{* * * *} \\
{[3.37]}\end{array}$ & $\begin{array}{l}0.069 * * * \\
{[3.21]}\end{array}$ & $\begin{array}{l}0.087^{* * *} \\
{[4.03]}\end{array}$ & $\begin{array}{l}-0.006 \\
{[0.33]}\end{array}$ \\
\hline Overvaluation & $\begin{array}{l}0.065^{* * *} \\
{[5.04]}\end{array}$ & $\begin{array}{l}0.045 * * \\
{[2.40]}\end{array}$ & $\begin{array}{l}0.077 * * * \\
{[5.59]}\end{array}$ & $\begin{array}{l}0.073 * * * \\
{[6.03]}\end{array}$ & $\begin{array}{l}0.004 \\
{[1.57]}\end{array}$ \\
\hline M2/GDP ratio & $\begin{array}{l}-0.017 * * * \\
{[4.16]}\end{array}$ & $\begin{array}{l}-0.014 * * \\
{[2.23]}\end{array}$ & $\begin{array}{l}-0.002 \\
{[0.42]}\end{array}$ & $\begin{array}{l}-0.016^{* * *} \\
{[3.91]}\end{array}$ & $\begin{array}{l}-0.004 \\
{[1.22]}\end{array}$ \\
\hline Incidence of exits & $\begin{array}{l}2.836^{* *} \\
{[2.10]}\end{array}$ & $\begin{array}{l}3.613^{*} \\
{[1.69]}\end{array}$ & $\begin{array}{l}1.312 \\
{[0.85]}\end{array}$ & $\begin{array}{l}1.622 \\
{[1.28]}\end{array}$ & $\begin{array}{l}5.183^{* *} \\
{[2.29]}\end{array}$ \\
\hline Volatility of terms of trade & $\begin{array}{l}0.018^{*} \\
{[1.85]}\end{array}$ & $\begin{array}{l}0.025^{* *} \\
{[2.04]}\end{array}$ & $\begin{array}{l}0.017 \\
{[1.41]}\end{array}$ & $\begin{array}{l}0.013^{* *} \\
{[2.12]}\end{array}$ & $\begin{array}{l}0.029^{* *} \\
{[1.96]}\end{array}$ \\
\hline GDP at current US dollars (in log) & $\begin{array}{l}0.258^{* * *} \\
{[3.22]}\end{array}$ & $\begin{array}{l}0.328 * * * \\
{[3.41]}\end{array}$ & $\begin{array}{l}0.071 \\
{[1.21]}\end{array}$ & $\begin{array}{l}0.254 * * * \\
{[3.73]}\end{array}$ & $\begin{array}{l}0.129 * * * \\
{[2.73]}\end{array}$ \\
\hline Foreign direct investment & $\begin{array}{l}0.094^{* *} \\
{[2.26]}\end{array}$ & $\begin{array}{l}0.076 \\
{[1.40]}\end{array}$ & $\begin{array}{l}0.037 \\
{[0.88]}\end{array}$ & $\begin{array}{l}0.057 \\
{[1.44]}\end{array}$ & $\begin{array}{l}0.006 \\
{[0.20]}\end{array}$ \\
\hline Volatility of investment & $\begin{array}{l}0.144^{* * *} \\
{[2.94]}\end{array}$ & $\begin{array}{l}0.154 * * \\
{[2.16]}\end{array}$ & $\begin{array}{l}0.071 \\
{[1.25]}\end{array}$ & $\begin{array}{l}0.129 * * * \\
{[2.91]}\end{array}$ & $\begin{array}{l}-0.045 \\
{[1.02]}\end{array}$ \\
\hline Capital controls & $\begin{array}{l}0.693^{* * *} \\
{[2.92]}\end{array}$ & $\begin{array}{l}0.727 * * \\
{[2.02]}\end{array}$ & $\begin{array}{l}0.858 * * * \\
{[4.08]}\end{array}$ & $\begin{array}{l}0.727^{* * * *} \\
{[3.30]}\end{array}$ & $\begin{array}{l}0.698^{* * *} \\
{[2.89]}\end{array}$ \\
\hline Observations & 393 & 309 & 346 & 429 & 234 \\
\hline Uncensored observations & 46 & 27 & 48 & 53 & 49 \\
\hline Censored observations & 347 & 282 & 298 & 376 & 185 \\
\hline Log pseudo-likelihood & -191.38 & & -216.95 & -226.15 & -241.43 \\
\hline Wald chi2 & 278.66 & 49.41 & 322.3 & 318.14 & 167.92 \\
\hline rho & 0.79 & 0.87 & 0.7 & 0.79 & 0.84 \\
\hline Wald test of indep. eqns. & 13 & & 9.16 & 16.21 & 2.15 \\
\hline Prob $>$ chi 2 & 0.000 & & 0.0025 & 0.0001 & 0.1426 \\
\hline Mill's ratio & & $\begin{array}{l}3.115^{* * * *} \\
{[2.64]}\end{array}$ & & & \\
\hline
\end{tabular}

Robust $\mathrm{z}$ statistics in brackets; ${ }^{*}$ significant at $10 \%,{ }^{* *}$ significant at $5 \%,{ }^{* *}$ significant at $1 \%$. Constant not reported. 
Table 8. Bivariate Probit Estimation: Orderly Exits with Exchange Rate Criterion

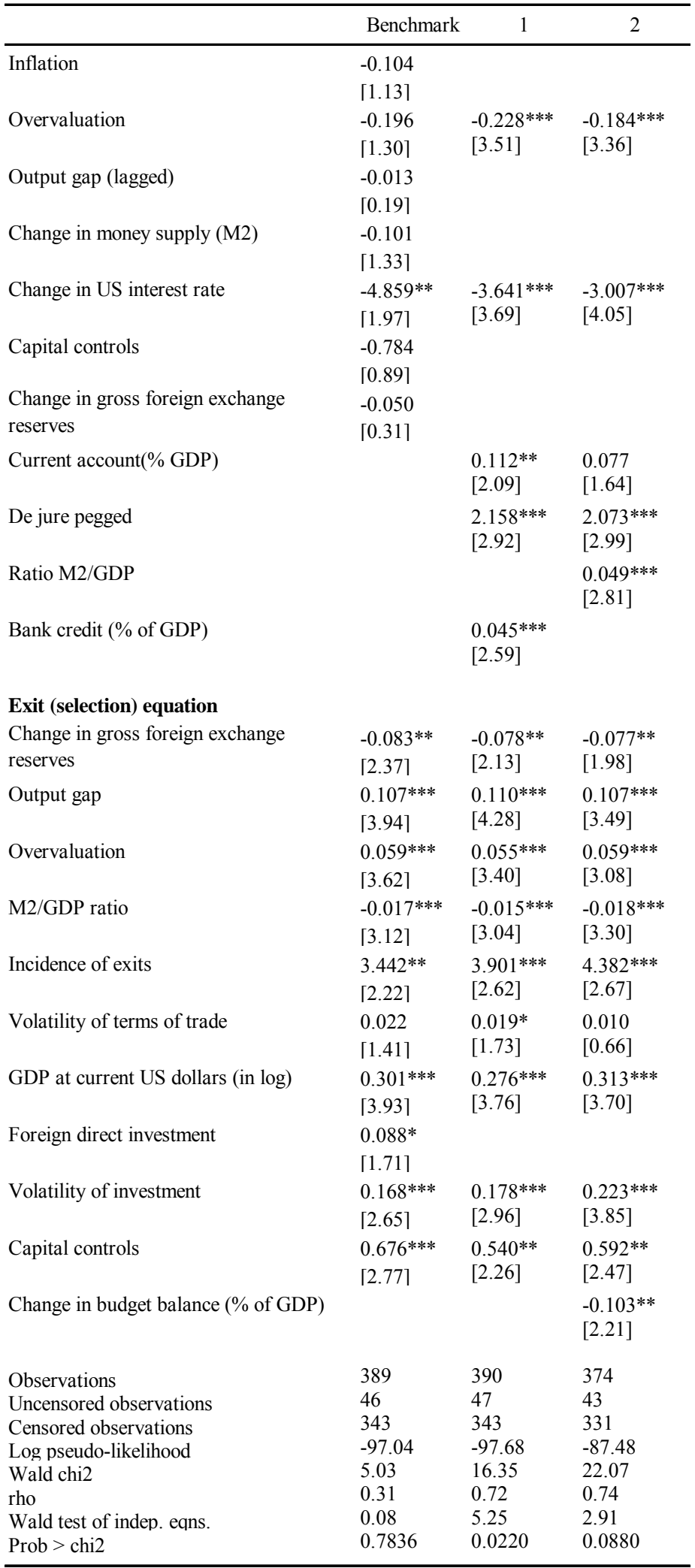

Robust $\mathrm{z}$ statistics in brackets; * significant at $10 \%, * *$ significant at $5 \%, * * *$ significant at $1 \%$. Constant not reported. 
Table 9. Bivariate Probit Estimation: Orderly Exits with Output Criterion

\begin{tabular}{|c|c|c|c|c|}
\hline & Benchmark & 1 & 2 & 3 \\
\hline Duration & $\begin{array}{l}-0.013^{* * *} \\
{[2.91]}\end{array}$ & $\begin{array}{l}-0.008 * * \\
{[2.21]}\end{array}$ & $\begin{array}{l}-0.011 * * * \\
{[2.78]}\end{array}$ & $\begin{array}{l}-0.006 \\
{[1.59]}\end{array}$ \\
\hline Output gap (lagged) & $\begin{array}{l}-0.518 * * * \\
{[2.73]}\end{array}$ & $\begin{array}{l}-0.494 * * * \\
{[3.47]}\end{array}$ & $\begin{array}{l}-0.523 * * * \\
{[2.60]}\end{array}$ & $\begin{array}{l}-0.561^{* * *} \\
{[3.33]}\end{array}$ \\
\hline Credit to the public sector & $\begin{array}{l}0.05 \\
{[1.49]}\end{array}$ & $\begin{array}{l}0.060^{* *} \\
{[2.15]}\end{array}$ & $\begin{array}{l}0.031 \\
{[1.11]}\end{array}$ & $\begin{array}{l}0.072 * * \\
{[2.31]}\end{array}$ \\
\hline $\begin{array}{l}\text { Ratio of liquid bank reserves to bank } \\
\text { assets }\end{array}$ & $\begin{array}{l}0.054 * * * \\
{[2.65]}\end{array}$ & $\begin{array}{l}0.042 * * \\
{[2.24]}\end{array}$ & $\begin{array}{l}0.081^{* * *} \\
{[2.59]}\end{array}$ & $\begin{array}{l}0.03 \\
{[1.16]}\end{array}$ \\
\hline Capital controls & $\begin{array}{l}1.813 * * * \\
{[2.66]}\end{array}$ & & $\begin{array}{l}2.461 * * * \\
{[3.08]}\end{array}$ & \\
\hline Foreign direct investment & $\begin{array}{l}0.359 \\
{[1.51]}\end{array}$ & $\begin{array}{l}0.357^{*} \\
{[1.73]}\end{array}$ & $\begin{array}{l}0.451^{* *} \\
{[2.04]}\end{array}$ & $\begin{array}{l}0.364^{*} \\
{[1.80]}\end{array}$ \\
\hline Openness & $\begin{array}{l}0.011^{*} \\
{[1.95]}\end{array}$ & $\begin{array}{l}0.005 \\
{[1.15]}\end{array}$ & & \\
\hline Change in money supply (M2) & & $\begin{array}{l}0.034^{*} \\
{[1.78]}\end{array}$ & & $\begin{array}{l}0.032 \\
{[1.59]}\end{array}$ \\
\hline Current account(\% GDP) & & & & $\begin{array}{l}-0.110^{*} \\
{[1.87]}\end{array}$ \\
\hline M2/GDP ratio & & & $\begin{array}{l}0.029^{*} \\
{[1.96]}\end{array}$ & \\
\hline \multicolumn{5}{|l|}{ Exit (selection) equation } \\
\hline $\begin{array}{l}\text { Change gross foreign exchange } \\
\text { reserves }\end{array}$ & $\begin{array}{l}-0.087 * * \\
{[2.52]}\end{array}$ & $\begin{array}{l}-0.085^{* *} \\
{[2.50]}\end{array}$ & $\begin{array}{l}-0.088^{* *} \\
{[2.57]}\end{array}$ & $\begin{array}{l}-0.087^{* *} \\
{[2.50]}\end{array}$ \\
\hline Output gap & $\begin{array}{l}0.105^{* * *} \\
{[4.05]}\end{array}$ & $\begin{array}{l}0.104 * * * \\
{[4.01]}\end{array}$ & $\begin{array}{l}0.105^{* * *} \\
{[4.02]}\end{array}$ & $\begin{array}{l}0.106^{* * *} \\
{[4.06]}\end{array}$ \\
\hline Overvaluation & $\begin{array}{l}0.060^{* * *} \\
{[3.90]}\end{array}$ & $\begin{array}{l}0.062^{* * * *} \\
{[4.15]}\end{array}$ & $\begin{array}{l}0.060^{* * *} \\
{[3.90]}\end{array}$ & $\begin{array}{l}0.060^{* * *} \\
{[4.05]}\end{array}$ \\
\hline M2/GDP ratio & $\begin{array}{l}-0.017 * * * \\
{[3.61]}\end{array}$ & $\begin{array}{l}-0.017 * * * \\
{[3.69]}\end{array}$ & $\begin{array}{l}-0.017 \text { *** } \\
{[3.55]}\end{array}$ & $\begin{array}{l}-0.018^{* * * *} \\
{[3.74]}\end{array}$ \\
\hline Incidence of exits & $\begin{array}{l}3.440^{* *} \\
{[2.34]}\end{array}$ & $\begin{array}{l}3.149^{* *} \\
{[2.15]}\end{array}$ & $\begin{array}{l}3.410^{* *} \\
{[2.38]}\end{array}$ & $\begin{array}{l}2.894 * \\
{[1.91]}\end{array}$ \\
\hline Volatility of terms of trade & $\begin{array}{l}0.023 * * \\
{[2.11]}\end{array}$ & $\begin{array}{l}0.025^{* * *} \\
{[2.59]}\end{array}$ & $\begin{array}{l}0.025 * * \\
{[2.50]}\end{array}$ & $\begin{array}{l}0.025^{* * *} \\
{[2.64]}\end{array}$ \\
\hline GDP at current US dollars (in log) & $\begin{array}{l}0.301 * * * \\
{[3.90]}\end{array}$ & $\begin{array}{l}0.306^{* * *} \\
{[4.00]}\end{array}$ & $\begin{array}{l}0.303 * * * \\
{[3.94]}\end{array}$ & $\begin{array}{l}0.305^{* * *} \\
{[3.97]}\end{array}$ \\
\hline Foreign direct investment & $\begin{array}{l}0.092 * * \\
{[2.19]}\end{array}$ & $\begin{array}{l}0.093^{* *} \\
{[2.20]}\end{array}$ & $\begin{array}{l}0.093 * * \\
{[2.17]}\end{array}$ & $\begin{array}{l}0.096^{* *} \\
{[2.20]}\end{array}$ \\
\hline Volatility of investment & $\begin{array}{l}0.161 \text { *** } \\
{[2.65]}\end{array}$ & $\begin{array}{l}0.156^{* *} \\
{[2.55]}\end{array}$ & $\begin{array}{l}0.157^{* * * *} \\
{[2.61]}\end{array}$ & $\begin{array}{l}0.156^{* * *} \\
{[2.58]}\end{array}$ \\
\hline Capital controls & $\begin{array}{l}0.677^{* * * *} \\
{[2.80]}\end{array}$ & $\begin{array}{l}0.630 * * * \\
{[2.72]}\end{array}$ & $\begin{array}{l}0.678 * * * \\
{[2.79]}\end{array}$ & $\begin{array}{l}0.642 * * * \\
{[2.76]}\end{array}$ \\
\hline Observations & 393 & 393 & 393 & 393 \\
\hline Uncensored observations & 46 & 46 & 46 & 46 \\
\hline Censored observations & 347 & 347 & 347 & 347 \\
\hline Log pseudo-likelihood & -98.39 & -99.01 & -97.92 & -98.38 \\
\hline Wald chi2 & 20.59 & 19.36 & 19.34 & 12.64 \\
\hline rho & 0.66 & 0.77 & 0.72 & 0.8 \\
\hline Wald test of indep. eqns. & 2.93 & 5.87 & 4.13 & 8.01 \\
\hline Prob $>$ chi 2 & 0.0871 & 0.0154 & 0.0422 & 0.0047 \\
\hline
\end{tabular}

Robust z statistics in brackets; * significant at 10\%, ** significant at 5\%, ${ }^{* * *}$ significant at $1 \%$. Constant not reported. 
Table 10. Summary of Results

\begin{tabular}{llcl}
\hline Event & \multicolumn{1}{c}{ Variable } & Effect $^{(1)}$ & \multicolumn{1}{c}{ Theoretical interpretation } \\
\hline Exit & Loss of reserves & + & Crisis models (first generation) \\
& Output gap & + & Crisis models (second generation) \\
& Overvaluation & + & Crisis models \\
M2/GDP ratio & + & ? \\
& Incidence of exits & + & Contagion \\
& Economic size & + & Choice of exchange regime, OCA \\
& Capital controls & + & Financial repression \\
Macro volatility & + & OCA \\
& FDI & + & Capital inflow problem \\
\hline Post-exit performance & & \\
& Inflation & - & OCA, governance \\
Overvaluation, duration & - & OCA \\
Output gap & $+/-$ & $?$ \\
Capital controls & + & Financial repression \\
Change in reserves & - & Crisis models \\
Change in US rate & - & Pull-push \\
FDI & + & Governance \\
Financial development & + & Financial repression \\
\hline
\end{tabular}

(1) Exit equation: $a+$ indicates that the exit probability rises.

Main equation: $\mathrm{a}+$ indicates that the exit conditions are more favorable; $+/$ - indicates different results according to the indicator used. 
Figure 1. Changes in the Exchange Rate and in the Output Gap

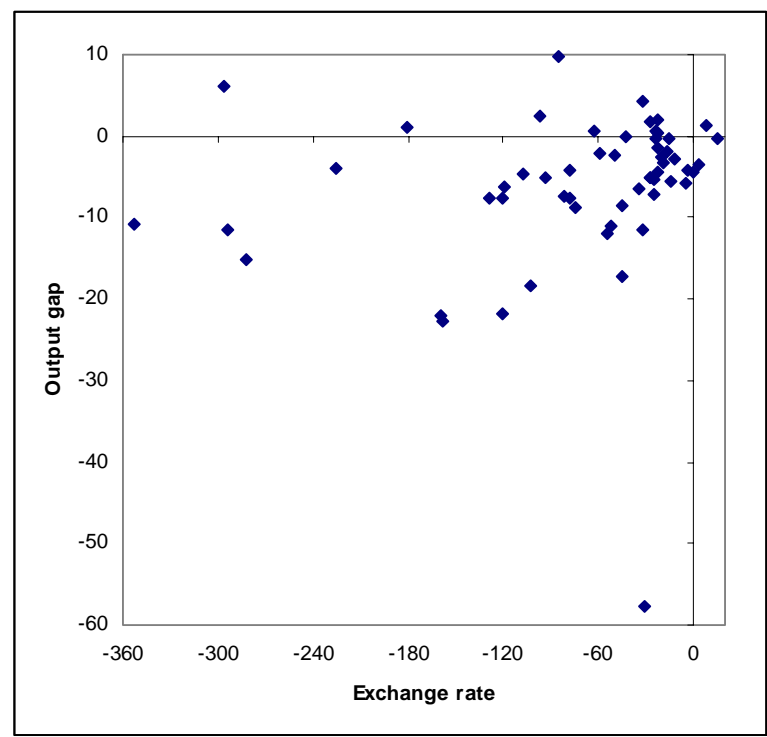

Figure 2. Distribution of Changes in the Exchange Rate and the Ouput Gap Change in the Exchange Rate Change in the Output Gap
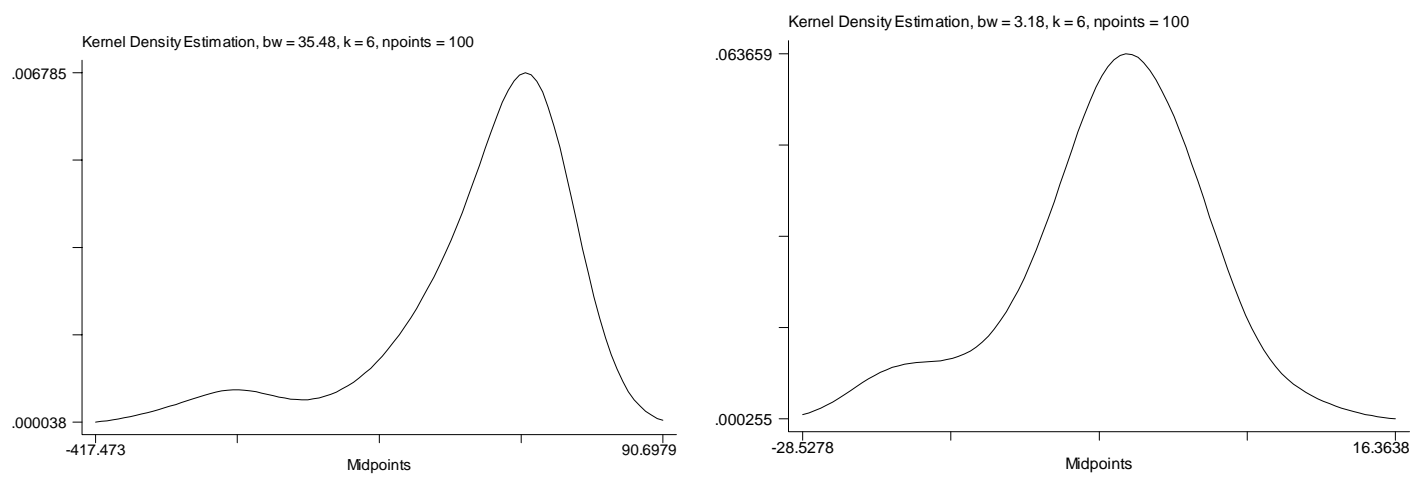


\section{Appendix}

The overall sample covers 128 countries, 103 developing countries and 25 developed countries over the period 1975-2000 (plus one observation on Turkey's exit in 2001). We start with 799 observations: 57 uncensored observations of exits and 742 censored observations of non-exits. As mentioned in the text, one observation correspond to a three-year window for one country. Tables A1 and A2 display the cases of exits and noexits, respectively. We exclude 201 no-exit observations for countries belonging to currency unions. Table A3 shows these cases. This leaves us with 598 observations covering 106 countries, 82 developing countries and 24 developed countries. The number of exiting countries is 49 (40 developing and 9 developed countries); indeed 6 developing countries and two developed countries have exited twice. The no-exit sample includes 57 countries that never exited and 39 countries that exited at least once. The data used are described in Table A5.

\section{Table A1. Exit Observations}

\begin{tabular}{|c|c|c|}
\hline Algeria (1988m1) & Iceland $(1975 \mathrm{~m} 8,2000 \mathrm{~m} 10)$ & Norway $(1982 \mathrm{~m} 8,1992 \mathrm{~m} 12)$ \\
\hline Argentina (1981m3) & Indonesia $(1997 \mathrm{~m} 8)$ & Paraguay (1981m9) \\
\hline Australia (1982m8) & Iran $(1978 \mathrm{~m} 11)$ & Philippines (1983m10, 1997m7) \\
\hline Brazil (1999m2) & Iraq $(1981 \mathrm{~m} 1)$ & Poland $(2000 \mathrm{~m} 4)$ \\
\hline Burundi (1996m5) & Italy (1976m1) & Russian Federation (1998m9) \\
\hline Chile $(1982 \mathrm{~m} 6,1999 \mathrm{~m} 9)$ & Japan $(1977 m 2)$ & Singapore $(1997 \mathrm{~m} 7)$ \\
\hline China $(1981 \mathrm{~m} 3)$ & Kenya $(1987 \mathrm{~m} 1)$ & Slovak Republic (1998m10) \\
\hline Colombia $(1983 \mathrm{~m} 5,1999 \mathrm{~m} 10)$ & Korea $(1997 \mathrm{~m} 12)$ & Suriname $(1982 \mathrm{~m} 5)$ \\
\hline Congo, Dem. Rep. (1975m1) & Lebanon (1984m3) & Sweden (1992m12) \\
\hline Costa Rica (1980m10) & Madagascar (1987m6) & Syria $(1982 \mathrm{~m} 6)$ \\
\hline Czech Republic (1997m6) & Mali $(1997 \mathrm{~m} 7)$ & Thailand (1997m7) \\
\hline Dominican Rep. (1982m9) & Malaysia (1997m8) & Turkey (1980m4, 2001m2) \\
\hline Ecuador $(1982 \mathrm{~m} 3,1999 \mathrm{~m} 3)$ & Mexico $(1982 \mathrm{~m} 2,1995 \mathrm{~m} 1)$ & United Kingdom (1992m9) \\
\hline El Salvador (1985m9) & Moldova (1998m8) & Uruguay $(1982 \mathrm{~m} 12)$ \\
\hline Greece $(1981 \mathrm{~m} 7)$ & New Zealand (1985m3) & Venezuela (1983m3) \\
\hline Guinea (1999m11) & Nicaragua (1979m4) & Zimbabwe (1983m7) \\
\hline Haiti (1993m5) & & \\
\hline
\end{tabular}

Note: The date is the month of exit. 


\section{Table A2. No-Exit Observations}

Algeria (1979,1982,1985,1997,2000)

Armenia (1997, 2000)

Australia $(1976,1979)$

Austria (1976,1979,1982,1985,1988, 1991,1994, 1997)

Azerbaijan (1997,2000)

Belgium (1979,1982,1985,1988, 1991,1994, 1997)

Bolivia (1988, 1991,1994, 1997, 2000)

Bosnia-Herzegovina (1997, 2000)

Botswana (1976,1979,1982,1985,1988, 1991,1994 1997, 2000)

Bulgaria (2000)

Burundi (1975,1978, 1981, 1984, 1987, 1990,

1993, 1999)

Canada $(1976,1979,1982,1985,1988,1991,1994$.

1997, 2000)

Chile (1979, 1990, 1993, 1996)

China $(1978,1994,1997,2000)$

Colombia (1977, 1980, 1987, 1990, 1993, 1996)

Costa Rica (1977, 1985, 1988, 1991, 1994, 1997,

2000)

Croatia $(1997,2000)$

Cyprus (1976,1979,1982,1985,1988, 1991,1994, 1997, 2000)

Czech Republic (1994)

Denmark (1976,1979,1982,1985,1988, 1991,1994, 1997, 2000)

Dominican Republic (1976, 1979, 1994, 1997, 2000)

Ecuador (1976, 1979, 1996)

Egypt (1976,1979,1982,1985,1988, 1991,1994, 1997, 2000)
Honduras (1976,1979,1982,1985,1988, 1991,1994, 1997, 2000)

Hong Kong (1976,1979,1982,1985,1988, 1991,1994, 1997, 2000)

1997, 2000)

Nepal $(1976,1979,1982,1985,1988,1991,1994,1997$. 2000)

Hungary $(1976,1979,1982,1985,1988,1991,1994,1997, \quad$ Netherlands $(1976,1979,1982,1985,1988,1991,1994$ 2000)

Iceland $(1985,1988,1991,1994,1997)$

India $(1976,1982,1985,1988,1991,1994,1997,2000)$

Indonesia $(1976,1979,1982,1985,1988,1991,1994)$

$\operatorname{Iraq}(1975,1978)$

Ireland $(1976,1979,1982,1985,1988,1991,1994,1997)$

Israel $(1988,1991,1994,1997,2000)$

Italy $(1985,1988,1991,1994,1997)$

Jamaica $(1976,1979,1982,1985,1988,1991,1994,1997$ 2000)

Jordan $(1976,1979,1982,1985,1988,1991,1994,1997$ 2000)

Kazakhstan (2000)

Kenya (1981, 1984)

Korea $(1976,1979,1982,1985,1988,1991,1994)$

Kuwait $(1976,1979,1982,1985,1988,1991,1994,1997$ 2000)

Latvia $(1997,2000)$

Lebanon (1975, 1978, 1981, 1994, 2000)

Liberia $(1976,1979,1982,1985,2000)$

Lithuania $(1997,2000)$

Luxembourg $(1976,1979,1982,1985,1988,1991,1994$

1997)

Macedonia (1994, 1997, 2000)

Madagascar (1978, 1981, 1984)
1997)

New Zealand $(1976,1979,1982)$

Nicaragua (1976, 1994, 1997, 2000)

Norway $(1976,1979,1989)$

Pakistan $(1976,1979,1982,1985,1988,1991,1994$

1997, 2000)

Panama (1976,1979,1982,1985,1988, 1991,1994, 1997, 2000)

Paraguay $(1975,1978,1988,1991,1994,1997,2000)$ Peru $(1997,2000)$

Philippines (1977,1980, 1988, 1991, 1994)

Poland (1997)

Portugal (1976,1979,1982,1985,1988, 1991,1994, 1997)

San Marino (1976,1979,1982,1985,1988, 1991,1994, 1997, 2000)

Saudi Arabia (1976,1979,1982,1985,1988, 1991,1994, 1997, 2000)

Singapore (1976,1979,1982,1985,1988, 1991,1994)

Slovak Republic (1995)

Slovenia (1994, 1997, 2000)

Spain $(1976,1979,1982,1985,1988,1991,1994,1997)$ Sri Lanka $(1976,1979,1982,1985,1988,1991,1994$, 1997, 2000)

Suriname (1976,1979, 1996, 1999)

Sweden $(1977,1980,1983,1986,1989)$

Switzerland (1985, 1988, 1991, 1994, 1997, 2000) 
El Salvador (1976,1979, 1994, 1997, 2000)

Estonia (1994, 1997, 2000)

Finland (1976,1979,1982,1985,1988, 1991,1994,

1997)

France $(1976,1979,1982,1985,1988,1991,1994$, 1997)

Gambia, The $(1976,1979,1994,1997,2000)$ Greece $(1975,1978,1988,1991,1994,1997)$ Guatemala (1976,1979,1982,1991,1994, 1997, 2000)

Guinea $(1987,1990,1993,1996)$

Haiti (1975, 1978, 1981, 1984, 1987, 1990)
Malaysia $(1976,1979,1982,1985,1988,1991,1994$, 2000)

Malta (1976,1979,1982,1985,1988, 1991,1994, 1997, 2000)

Marshall Islands (1976,1979,1982,1985,1988,

1991,1994, 1997, 2000)

Mauritania (1976,1979,1982,1985,1988, 1991,1994,

1997, 2000)

Mauritius (1979,1982,1985,1988, 1991,1994, 1997,

2000)

Mexico $(1979,1992)$

Micronesia, Federated States of $(1988,1991,1994,1997$, 2000)

Monaco (1976,1979,1982,1985,1988, 1991,1994, 1997,

2000)

Mongolia (2000)
Syrian Arab Republic (1976,1979,1991,1994, 1997, 2000)

Tanzania $(1997,2000)$

Thailand (1976,1979,1982,1985,1988, 1991,1994)

Tunisia $(1976,1979,1982,1985,1988,1991,1994,1997$, 2000)

\section{Turkey (1977)}

Uganda (1988, 1991,1994, 1997, 2000)

Ukraine (2000)

Uruguay $(1976,1979,1994,1997,2000)$

Venezuela $(1977,1980,2000)$. 


\section{Table A3. Excluded Observations}

1. Currency union members throughout the sample period

$\begin{array}{lll}\text { Antigua and Barbuda } & \text { Dominica } & \text { Niger } \\ \text { Benin } & \text { Equatorial Guinea } & \text { Saint Kitts and Nevis } \\ \text { Burkina Faso } & \text { Gabon } & \text { Saint Lucia } \\ \text { Cameroon } & \text { Grenada } & \text { Saint Vincent and the Grenadines } \\ \text { Central African Republic } & \text { Guinea-Bissau } & \text { Senegal } \\ \text { Chad } & \text { Lesotho } & \text { Swaziland } \\ \text { Cote d'Ivoire } & \text { Mali } & \text { Togo }\end{array}$

2. Currency union members during part of the sample period

$\begin{array}{lll}\text { Austria (2000) } & \text { Greece (2000) } & \text { Luxembourg (2000) } \\ \text { Belgium (2000) } & \text { Ireland (2000) } & \text { Netherlands (2000) } \\ \text { Finland (2000) } & \text { Italy (2000) } & \text { Portugal (2000) } \\ \text { France (2000) } & \text { Kenya }(1975,1978) & \text { Spain (2000) } \\ \text { Germany (2000) } & & \end{array}$


Table A4. Classification of Orderly Exits

\begin{tabular}{|c|c|c|c|c|c|c|c|}
\hline Country & Exit month & $\begin{array}{l}\text { Exchange } \\
\text { rate } \\
\text { criterion } \\
\end{array}$ & $\begin{array}{l}\text { Output } \\
\text { criterion }\end{array}$ & Country & Exit month & $\begin{array}{c}\text { Exchange } \\
\text { rate } \\
\text { criterion } \\
\end{array}$ & $\begin{array}{c}\text { Output } \\
\text { criterion }\end{array}$ \\
\hline Algeria & $1988 \mathrm{~m} 1$ & 1 & 1 & Lebanon & $1984 \mathrm{~m} 3$ & 0 & \\
\hline Argentina & $1981 \mathrm{~m} 3$ & 0 & 0 & Madagascar & $1987 \mathrm{~m} 6$ & 0 & 1 \\
\hline Australia & $1982 \mathrm{~m} 8$ & 1 & 0 & Malawi & $1997 \mathrm{~m} 7$ & 0 & 1 \\
\hline Brazil & $1999 \mathrm{~m} 2$ & 0 & 1 & Malaysia & $1997 \mathrm{~m} 8$ & 0 & 0 \\
\hline Burundi & $1996 \mathrm{~m} 5$ & 1 & 0 & Mexico & $1982 \mathrm{~m} 2$ & 0 & 0 \\
\hline Chile & $1982 \mathrm{~m} 6$ & 0 & 0 & Mexico & $1995 \mathrm{~m} 1$ & 0 & 0 \\
\hline Chile & 1999m9 & 1 & 0 & Moldova & $1998 \mathrm{~m} 8$ & 0 & 1 \\
\hline China & $1981 \mathrm{~m} 3$ & 1 & 0 & New Zealand & $1985 \mathrm{~m} 3$ & 1 & 1 \\
\hline Colombia & $1983 \mathrm{~m} 5$ & 0 & 1 & Nicaragua & $1979 m 4$ & 0 & 0 \\
\hline Colombia & $1999 \mathrm{~m} 10$ & 0 & 0 & Norway & $1982 \mathrm{~m} 8$ & 1 & 1 \\
\hline Congo, Dem. Rep. & $1975 \mathrm{~m} 1$ & 0 & 0 & Norway & $1992 \mathrm{~m} 12$ & 1 & 1 \\
\hline Costa Rica & $1980 \mathrm{~m} 10$ & 0 & 0 & Paraguay & $1981 \mathrm{~m} 9$ & 1 & 0 \\
\hline Czech Republic & $1997 \mathrm{~m} 6$ & 0 & 0 & Philippines & $1983 \mathrm{~m} 10$ & 0 & 0 \\
\hline Dominican Republic & $1982 \mathrm{~m} 9$ & 1 & 1 & Philippines & $1997 \mathrm{~m} 7$ & 0 & 1 \\
\hline Ecuador & $1982 \mathrm{~m} 3$ & 0 & 0 & Poland & $2000 \mathrm{~m} 4$ & 1 & 1 \\
\hline Ecuador & $1999 \mathrm{~m} 3$ & 0 & 0 & Russia & $1998 \mathrm{~m} 9$ & 0 & 1 \\
\hline El Salvador & $1985 \mathrm{~m} 9$ & 0 & 1 & Singapore & $1997 \mathrm{~m} 7$ & 1 & 0 \\
\hline Greece & $1981 \mathrm{~m} 7$ & 0 & 0 & Slovak Republic & $1998 \mathrm{~m} 10$ & 1 & 1 \\
\hline Guinea & 1999m11 & 1 & 1 & Suriname & $1982 \mathrm{~m} 5$ & 0 & 0 \\
\hline Haiti & $1993 \mathrm{~m} 5$ & 0 & 0 & Sweden & $1992 \mathrm{~m} 12$ & 0 & 0 \\
\hline Iceland & $1975 \mathrm{~m} 8$ & 0 & 0 & Syrian & $1982 \mathrm{~m} 6$ & 1 & 0 \\
\hline Iceland & $2000 \mathrm{~m} 10$ & 0 & 1 & Thailand & $1997 \mathrm{~m} 7$ & 0 & 0 \\
\hline Indonesia & $1997 \mathrm{~m} 8$ & 0 & 0 & Turkey & $1980 \mathrm{~m} 4$ & 0 & 0 \\
\hline Iran & $1978 \mathrm{~m} 11$ & 0 & 0 & Turkey & $2001 \mathrm{~m} 2$ & 0 & 0 \\
\hline Iraq & $1981 \mathrm{~m} 1$ & 0 & 0 & United Kingdom & $1992 \mathrm{~m} 9$ & 1 & 1 \\
\hline Italy & $1976 \mathrm{~m} 1$ & 1 & 1 & Uruguay & $1982 \mathrm{~m} 12$ & 0 & 0 \\
\hline Japan & $1977 \mathrm{~m} 2$ & 1 & 1 & Venezuela & $1983 \mathrm{~m} 3$ & 0 & 0 \\
\hline Kenya & $1987 \mathrm{ml}$ & 0 & 1 & Zimbabwe & $1983 \mathrm{~m} 7$ & 0 & 0 \\
\hline Korea & $1997 \mathrm{~m} 12$ & 0 & 0 & Total & 57 & 18 & 21 \\
\hline
\end{tabular}

Exchange rate criterion: orderly if the exchange rate depreciates by less than $25 \%$ between month $\mathrm{t}-6$ and month $1+12$.

Output gap criterion: orderly if the output gap declines by less than $3 \%$ between year $\mathrm{t}-1$ and $\mathrm{t}+1$. 
Table A5. Data Definitions and Sources

\begin{tabular}{|c|c|c|c|}
\hline Variable & Description & Frequency & Source \\
\hline Exchange rate & Appreciation (\%) between $\mathrm{t}-6$ and $\mathrm{t}+6$ & Monthly & R\&R (2004) and IFS (line AG) \\
\hline Budget Balance & Budget Balance (\% GDP) & Annual & WDI, IFS, and national sources \\
\hline Current Account Balance & Current Account Balance (\% GDP) & Annual & WDI and Ghosh et al. (2003) \\
\hline Openness & Trade in goods and services (\% GDP) & Annual & WDI \\
\hline Foreign Direct Investment & Foreign direct investment (\% GDP) & Annual & WDI \\
\hline Financial Depth & Liquid Liabilites, M3 (\% GDP) & Annual & World Bank Financial Structure Dataset \\
\hline Private Credit & Private Credit (\% GDP) & Annual & World Bank Financial Structure Dataset \\
\hline Inflation & Inflation rate & Monthly & IFS (line 64) \\
\hline Change in Gross Reserves & Change in Gross Reserves (\% GDP), annual GDP intrapolated to monthly frequency & Monthly & IFS (line 11) \\
\hline Output Gap & Deviation of Output from HP Trend, GDP constant local currency & Annual & WDI \\
\hline External Public Debt & External Public Debt (\% GDP) & Annual & WDI \\
\hline Overvaluation & Deviation of quarterly real effective exchange rate from HP trend & Annual & IFS (REC or REU), otherwise authors calculations (1) \\
\hline Volatility of Terms of Trade & Standard deviation of TOT over the last 5 years & Annual & WEO (2003) and Ghosh et al.(2003) \\
\hline Volatility of Investments & Standard deviation of Gross Fixed Capital formation to GDP & Annual & IFS (line 93e) and WDI \\
\hline Incidence of Exits & Number of exits in year i divided by total number of exits & Annual & Authors' calculation \\
\hline Change in US interest rate & Change in US Federal Funds' Rate & Monthly & IFS (line 60b) \\
\hline Share of exports to reference currency country & Share of exports to reference currency country & Annual & Bilateral Export figures from DOTS (2004) \\
\hline GDP & Logarithm of GDP (Current Dollars ) & Annual & WDI \\
\hline Capital Control Dummy & Capital Account Restriction dummy & Annual & Ghosh et al.(2003) \\
\hline M2GDP & M2 (\% GDP) & Annual & M2: IFS (line 34 and 35), GDP: IFS (line 99b) or WDI \\
\hline Change in Money Supply (M2) & Growth rate of M2 & Annual & IFS (lines 34 and 35) \\
\hline Duration & Number of months under the fixed exchange rate regime before the exit & Monthly & $\mathrm{R} \& \mathrm{R}(2004)$ \\
\hline Credit to the Publis Sector & Credit to the public sector (\% GDP) & Annual & IFS (line 32 - line 32d) \\
\hline Net oil exporter country dummy & Net oil exporter country dummy & Annual & Authors' calculations \\
\hline Liquid Bank Reserves to Bank Assets & Ratio of liquid Bank Reserves to Bank Assets & Annual & DWI \\
\hline Change in Real Money Supply (M2) & Change in ratio $\mathrm{M} 2 / \mathrm{GDP}$ & Annual & IFS (lines 34,35 and 64) \\
\hline
\end{tabular}

IFS: International Financial Statistics International Monetary Fund

WDI: World Development Indicators, World Bank

World Bank Financial Structure Dataset, http://www.worldbank.org/research/projects/finstructure/database.htm

(1) Geometric average of CPI-deflated exchange rate vis a vis US\$, DM and yen with equal weights 